\title{
İnşaat Sektöründeki İş Kazalarının Hata Ăgacı Analizi ile Değerlendirilmesi
}

\author{
Şerife AK ${ }^{1}$ \\ İsmail ZORLUER ${ }^{2}$
}

\section{ÖZ}

İnşaat sektörü hem dünyada hem de Türkiye'de en çok iş kazasının yaşandığı sektörlerin başında gelmektedir. Ölüm, yaralanma, sürekli iş görmezlik veya meslek hastalıklarıyla sonuçlanan iş kazalarının nedenlerinin belirlenmesi, iş kazalarına karşı önlemler alınması güncelliğini koruyan önemli bir problemdir.

Bu çalışma kapsamında Türkiye'de inşaat sektöründe farklı zamanlarda meydana gelen iş kazalarının ölüm ve yaralanma oranlarından yararlanılarak hata ağacı analizi gerçekleştirilmiştir. Hata ağacının istenmeyen tepe olayı, iş kazası olarak tanımlanmıştır. Hata ağacı yapısı, iş kazalarını ve nedenlerini ilişkilendiren minimum kesme kümelerinden oluşmaktadır. Tümdengelimsel bir yaklaşımla hesaplamaların gerçekleştirildiği hata ağacı analizinde, minimum kesme kümelerinin ve istenmeyen tepe olayın hata olasılığı değerleri hesaplanırken Boolean matematiğinden yararlanılmaktadır.

Çalışma kapsamında hem iş kazalarının meydana gelme olasılıkları hem de hata olarak tanımlanan iş kazalarının kritik önem faktörleri ortaya konmuştur. İş kazalarına karşı alınacak önlemler sıralamasında, göreceli olarak minimum kesme kümelerinin olasılık değerleri dikkate alınabileceği gibi kritik önem faktörlerinin de bir sıralama ölçütü olarak kullanılabileceği sonucuna varılmıştır. Çalışma, hata ağacı analizinin Türkiye'deki iş kazalarının analizinde etkin bir şekilde kullanılabileceğini göstermektedir. Ayrıca bu çalışmada oluşturulan hata ağacı yapısı ile yetkili mercilerin gerekli önlemleri alabilmesi açısından görsel bir model ortaya koyulmuştur.

Anahtar Kelimeler: İnşaat sektörü, iş kazaları, hata ağacı analizi, risk analizi.

\footnotetext{
Not: Bu yazı

- Yayın Kurulu'na 11 Ocak 2021 günü ulaşmıştır. 29 Kasım 2021 günü yayımlanmak üzere kabul edilmiştir.

- 31 Ocak 2023 gününe kadar tartışmaya açıktır.

- https://doi.org/10.18400/tekderg.858275

1 Afyon Kocatepe Üniversitesi, İnşaat Mühendisliği Bölümü, Afyonkarahisar sgokce@aku.edu.tr - https://orcid.org/0000-0003-3854-8226

2 Afyon Kocatepe Üniversitesi, İnşaat Mühendisliği Bölümü, Afyonkarahisar izorluer@aku.edu.tr - https://orcid.org/0000-0001-5017-084X
} 


\section{ABSTRACT \\ Evaluation of Occupational Accidents in the Construction Industry with Fault Tree Analysis}

The majority of the numbers of occupational accidents occurred due to the construction industry both in Turkey and all over the world. Determining the causes of occupational accidents resulting in death, injury, permanent incapacity, or occupational diseases is necessary at present; thus, precautions against occupational accidents can be determined and applied.

Fault tree analysis was applied by using the death and injury rates of occupational accidents at different times in the construction industry in Turkey in this study. The undesired top event of the fault tree was defined as an occupational accident. The fault tree structure consists of minimum cut sets relating to occupational accidents and their causes. In fault tree analysis, where calculations were performed with a deductive approach, Boolean algebra calculated the unavailability values of the minimum cut sets and the undesired top event.

Both the possibilities of occupational accidents and the critical importance factors of the occupational accidents defined as errors are revealed. It has been concluded that relatively the probability values of the minimal cut sets can be taken into account, and the critical importance factors can be used as a ranking criterion in the order of measures to be taken against occupational accidents. The study displays that fault tree analysis can be used effectively to analyze occupational accidents in Turkey. In addition, with the fault tree structure created in this study, a visual model was presented for the competent authorities to take the necessary precautions.

Keywords: Construction industry, occupational accidents, fault tree analysis, risk analysis.

\section{GíRiş}

İş kazasının literatürde pek çok tanımı bulunmaktadır. Uluslararası Çalışma Örgütü (International Labour Organization) iş kazasını, bir veya birden fazla işçinin ölümüne, yaralanmasına veya hastalığına neden olan, işten kaynaklanan veya iş ile bağlantılı olarak ortaya çıkan şiddet eylemleri de dahil olmak üzere beklenmedik ve planlanmamış olay şeklinde ifade etmektedir [1]. Uluslararası Çalışma Örgütü’ne göre bir ekonomik faaliyet sırasında meydana gelen ulaşım ve trafik kazaları da iş kazası kapsamında değerlendirilmektedir. Ülkemizde 2012 yılında yürürlüğe giren 6331 Sayılı İş Sağlığı ve Güvenliği Kanunu'na göre iş kazası, "işyerinde veya işin yürütümü nedeniyle meydana gelen, ölüme sebebiyet veren veya vücut bütünlüğünü ruhen ya da bedenen engelli hâle getiren olay" olarak tanımlanmaktadır [2]. Teknolojinin gelişmesi, ekonomik faaliyetlerin her geçen gün artması gibi nedenlerden dolayı dünya üzerinde her yıl pek çok insan iş kazaları nedeniyle ölmekte, yaralanmakta veya meslek hastalığına yakalanmaktadır. Çok sayıda malzeme ve ekipman kullanımı gerektiren sektörlerde, nispeten insan hareketleri de artmaktadır. Buna paralel olarak iş kazası meydana gelme olasılığının arttı̆̆ını da söylemek mümkün olmaktadır.

Geçmişten günümüze, inşaat sektöründe iş kazalarının ve bu kazaların neden olduğu olumsuz sonuçların önlenmesi veya azaltılmasına ilişkin pek çok çalışma ve yasal düzenleme 
gerçekleştirilmiştir. Bu çalışma ve düzenlemelere rağmen inşaat sektörü [3-5] halen hem dünyada hem de Türkiye'de iş kazasının en çok yaşandığ 1 sektörlerden biri olarak karşımıza çıkmaktadır. İnşaat işleri, doğası gereği dinamik olduğundan [6] dış etkenlerden oldukça fazla etkilenmektedir. İnşaat faaliyetlerinde çeşitli ve çok sayıda malzeme ve ekipman kullanılmaktadır. İnşaat işlerinde ağırlıklı olarak vasıfsız işçiler çalışmaktadır. Belirli bir zaman diliminde işlerin yetiştirilmesi gerektiğinden hızlı ve çoğunlukla dikkatsiz çalışma yapılmaktadır. Yıllar içerisinde sektörün çoğunlukla büyüme trendi göstermesi, çalışan iş̧̧i sayısının da artmasına neden olmaktadır. Bütün bu nedenler inşaat sektörünü iş kazasına açık ve riskli bir sektör haline getirmektedir.

Literatürde iş kazalarının, kaza analiz çalı̧̧maları, kaza önleme çalışmaları ve risk değerlendirme çalışmaları olarak üç ana grupta ele alındığı görülmektedir [7]. Literatürdeki çalışmalara inşaat sektörü perspektifinden bakıldığında;

i) iş kazası analizine [3,7-17], ii) iş kazası önlenmesine [18-25], iii) iş kazalarında risk değerlendirmesine [26-33], iv) ve modellemeye [11, 20, 29] yönelik pek çok çalışma bulunmaktadır.

$\mathrm{Bu}$ çalı̧̧a kapsamında yukarıda belirtilen üç ana gruptan, risk değerlendirmesi grubunda ele alınabilecek bir uygulama gerçekleştirilmiş̧ir. Çalışma kapsamında Gürcanlı ve Müngen (2013) [34] tarafından sınıflandırılan iş kazası verileri kullanılarak hata ağacı analizi ile risk değerlendirmesi yapılmıştır.

Literatürde hata ağacı analizinin inşaat sektöründeki iş kazalarına uygulandı̆̆ı çalışmalar da bulunmaktadır. Hadiprino (1992) [35], inşaatlarda meydana gelen düşme kazalarını ve bu kazaların nedenlerini araştırarak hata ağacı analizi yöntemi ile analiz etmiş̧ir. Düşmelerin nedenleri, çalışanın kişisel özelliklerine bağlı nedenler, çalışanın düşmesine neden olan dolaylı nedenler ve çalışma ortamından kaynaklanan düşmeler şeklinde üç gruba ayrılmıştır. $\mathrm{Bu}$ üç gruba neden olabilecek basit ve koşullu olaylar belirlenerek hata ağacı analizi gerçekleştirilmiştir.

Hadiprino (1992) [36], önceki çalışmasının ikinci bölümü olan çalışmasında ise inşaatlarda meydana gelen düşme kaynaklı kazaların simülasyonunu yaparak FTES-FALL adını verdiği hata ağacı uzman sistemi geliştirmiştir.

LeBeau ve diğ. (2007) [37], hata ağacı analizi aracılı̆̆ıyla köprülerde meydana gelen çökmeleri ve bunların nedenlerini incelemişlerdir. Ortaya koydukları grafiksel hata ağacı modeli ile benzer köprü tiplerinin yapımı esnasında kritik yönlere dikkat çekmeyi hedeflenmişlerdir.

Chi ve diğ. (2014) [28], çalışmalarında inşaat sektöründeki ölümlü iş kazalarını inceleyerek, bu kazalar ve nedenleri arasındaki ilişkilendirmeyi hata ağacı analizi aracılığıyla gerçekleştirmişlerdir. Düşmelerden kaynaklanan ölümlerin nedenlerinin belirlenmesinde, oluşturdukları grafiksel hata ağacının etkili olarak kullanılabileceğini ortaya koymuşlardır.

Yang ve Deng (2021) [38] tünel inşaatındaki risk kaynaklarını belirledikleri çalışmalarında hata ağacı analizi ile nitel ve nicel analiz gerçekleştirmişlerdir. Çalışmalarında örnek olarak ele aldıkları tünelin çökmesini etkileyen faktörleri önemine göre sıralamışlardır.

Bu çalışma kapsamında, Gürcanlı ve Müngen (2013) [34] tarafindan incelenen ve sınıflandırılan iş kazalarına ait kök neden belirleme çalışması gerçekleştirilmiş̧tir. Belirlenen 
kök nedenlere bağlı olarak hata ağacı oluşturulmuştur. İstenmeyen olayın iş kazası olarak ele alındığı çalışmada, hata ağacını oluşturan minimum kesme kümeleri modellenmiştir. Modelin analiz edilmesiyle Türkiye'de meydana gelen iş kazalarının hata olasılığı değerleri ve kritik önem faktörleri belirlenmiştir.

\section{2. İNSSAAT SEKTÖRÜNDE İS KAZALARI VE İS KAZASI TIPPLERİ}

Türkiye'de çeşitli faaliyet gruplarında meydana gelen kazalara ilişkin veriler Sosyal Güvenlik Kurumu (SGK) tarafından açıklanmaktadır. Türkiye İstatistik Kurumu yıllara göre iş kazası ve meslek hastalıkları istatistiklerinden derlenen sayılar Tablo 1' de verilmiştir. Tablo 1'de 2007-2019 yılları arasında Türkiye'de meydana gelen iş kazası, ölüm, sürekli iş görmezlik, meslek hastalığı sayılarının ve kaza sıklıklarının inşaat sektöründeki sayılarla karşılaştırmaları görülmektedir. SGK’nın 2007 yılı öncesi için açıkladığı veriler detaylı olarak incelendiğinde Tablo 1'de verilen kaza sıklık değerlerini elde etmek için yeterli bilgi bulunmamaktadır. Kaza sıklığı, her 100.000 çalışan başına düşen iş kazası sayısı olarak ifade edilmektedir [39] ve aşağıdaki eşitlik ile hesaplanmaktadır:

$$
\text { Kaza Sıklığı }=\frac{\text { Kaza Sayısı } \bullet 100.000}{\text { Çalışan İşçi Sayısı }}
$$

Tablo 1 - Yıllara Göre Türkiye Genelinde ve İşsaat Sektöründe İş Kazası Verileri

\begin{tabular}{|c|c|c|c|c|c|c|c|c|c|}
\hline & \multicolumn{2}{|c|}{$\begin{array}{l}\text { İș Kazası Sayıları } \\
\text { (Kaza Sıklığı) }\end{array}$} & \multicolumn{2}{|c|}{$\begin{array}{c}\text { Ölüm Sayısı (Kaza } \\
\text { Sıklığı) }\end{array}$} & \multicolumn{2}{|c|}{$\begin{array}{c}\text { Sürekli İş } \\
\text { Görmezlik (Kaza } \\
\text { Sıklığı) }\end{array}$} & \multicolumn{2}{|c|}{$\begin{array}{l}\text { Meslek Hastalı̆̆ } 1 \\
\text { (Kaza S1klığ } 1 \text { ) }\end{array}$} \\
\hline & & $\begin{array}{l}\text { Türkiye } \\
\text { Geneli }\end{array}$ & $\begin{array}{l}\text { İnşaat } \\
\text { Sektörü }\end{array}$ & $\begin{array}{l}\text { Türkiye } \\
\text { Geneli }\end{array}$ & $\begin{array}{c}\text { İnşaat } \\
\text { Sektörü }\end{array}$ & $\begin{array}{l}\text { Türkiye } \\
\text { Geneli }\end{array}$ & $\begin{array}{l}\text { İnşaat } \\
\text { Sektörü }\end{array}$ & $\begin{array}{l}\text { Türkiye } \\
\text { Geneli }\end{array}$ & $\begin{array}{l}\text { İnşaat } \\
\text { Sektörü }\end{array}$ \\
\hline \multirow{6}{*}{ 冞 } & 2007 & $\begin{array}{c}80602 \\
(947,66)\end{array}$ & $\begin{array}{c}7615 \\
(610,19)\end{array}$ & $\begin{array}{c}1044 \\
(12,27)\end{array}$ & $\begin{array}{c}359 \\
(28,77)\end{array}$ & $\begin{array}{c}1956 \\
(23,00)\end{array}$ & $\begin{array}{c}364 \\
(29,17)\end{array}$ & $\begin{array}{c}1208 \\
(14,20)\end{array}$ & $\begin{array}{c}16 \\
(1,28)\end{array}$ \\
\hline & 2008 & $\begin{array}{c}72963 \\
(828,84)\end{array}$ & $\begin{array}{c}5574 \\
(449,92)\end{array}$ & $\begin{array}{c}866 \\
(9,84)\end{array}$ & $\begin{array}{c}297 \\
(23,97)\end{array}$ & $\begin{array}{c}1694 \\
(19,24)\end{array}$ & $\begin{array}{c}377 \\
(30,43)\end{array}$ & $\begin{array}{c}539 \\
(6,12)\end{array}$ & $\begin{array}{c}6 \\
(0,48)\end{array}$ \\
\hline & 2009 & $\begin{array}{r}64316 \\
(712,23) \\
\end{array}$ & $\begin{array}{c}6877 \\
(560,15)\end{array}$ & $\begin{array}{c}1171 \\
(12,97)\end{array}$ & $\begin{array}{c}156 \\
(12,71)\end{array}$ & $\begin{array}{c}1885 \\
(20,87)\end{array}$ & $\begin{array}{c}284 \\
(23,13)\end{array}$ & $\begin{array}{c}429 \\
(4,75)\end{array}$ & $\begin{array}{c}9 \\
(0,73)\end{array}$ \\
\hline & 2010 & $\begin{array}{r}62903 \\
(4337,27) \\
\end{array}$ & $\begin{array}{r}6437 \\
(64,17) \\
\end{array}$ & $\begin{array}{c}1454 \\
(100,26) \\
\end{array}$ & $\begin{array}{c}475 \\
(4,74)\end{array}$ & $\begin{array}{c}2085 \\
(143,76)\end{array}$ & $\begin{array}{c}319 \\
(3,18)\end{array}$ & $\begin{array}{c}533 \\
(36,75) \\
\end{array}$ & $\begin{array}{c}31 \\
(0,31) \\
\end{array}$ \\
\hline & 2011 & $\begin{array}{c}69227 \\
(627,57)\end{array}$ & $\begin{array}{c}7749 \\
(475,15)\end{array}$ & $\begin{array}{c}1710 \\
(15,50)\end{array}$ & $\begin{array}{c}570 \\
(34,95)\end{array}$ & $\begin{array}{c}2216 \\
(20,09)\end{array}$ & $\begin{array}{c}406 \\
(24,89)\end{array}$ & $\begin{array}{c}697 \\
(6,32)\end{array}$ & $\begin{array}{c}16 \\
(0,98)\end{array}$ \\
\hline & 2012 & $\begin{array}{c}74871 \\
(627,08)\end{array}$ & $\begin{array}{c}9209 \\
(514,62)\end{array}$ & $\begin{array}{c}745 \\
(6,24)\end{array}$ & $\begin{array}{c}256 \\
(14,31)\end{array}$ & $\begin{array}{c}2209 \\
(18,50)\end{array}$ & $\begin{array}{c}568 \\
(31,74)\end{array}$ & $\begin{array}{c}395 \\
(3,31)\end{array}$ & $\begin{array}{c}30 \\
(1,68)\end{array}$ \\
\hline
\end{tabular}


Tablo 1 - Yıllara Göre Türkiye Genelinde ve Inşaat Sektöründe İş Kazası Verileri (devam)

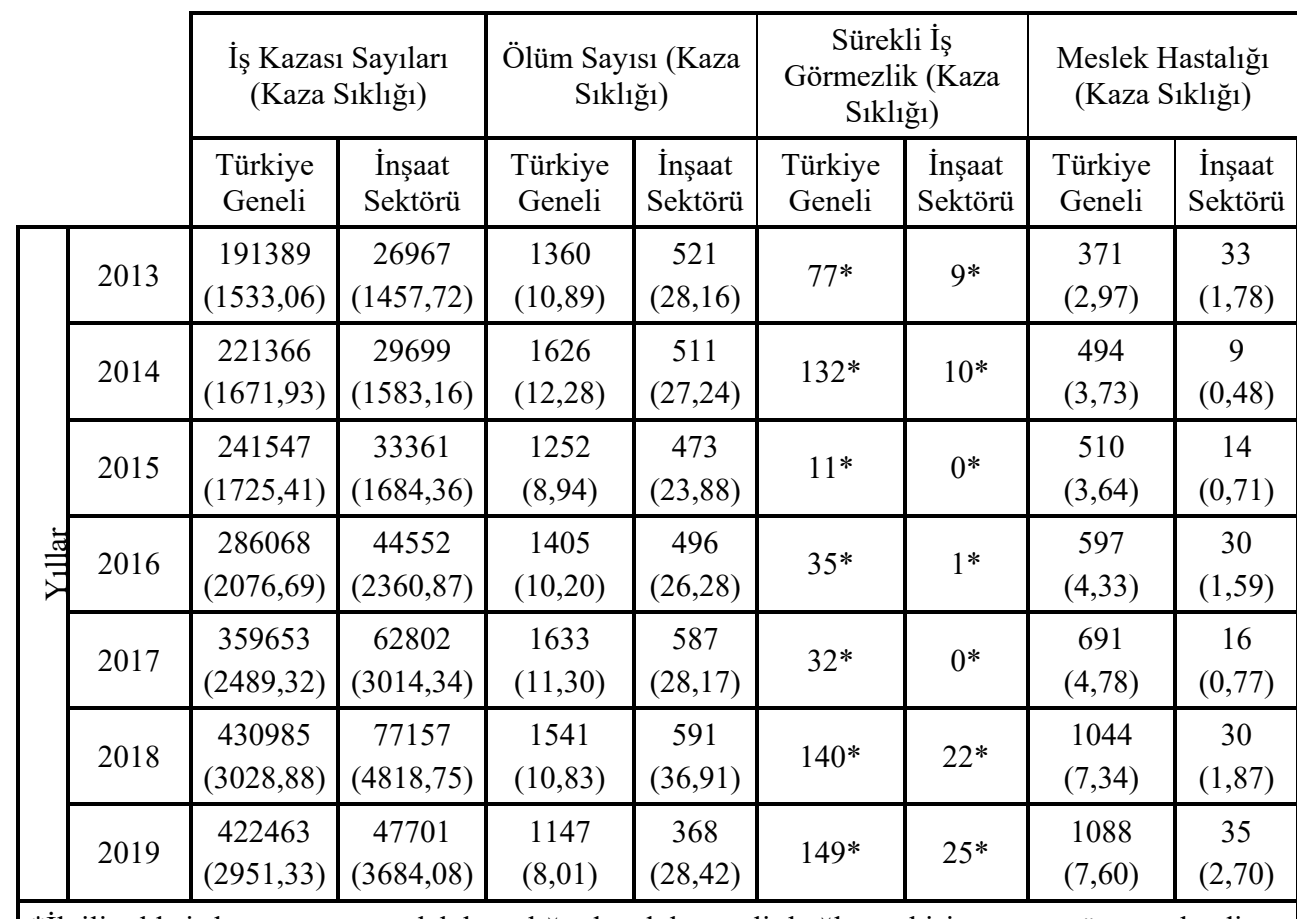

*İlgili yılda iş kazası veya meslek hastalığından dolayı gelir bağlanan kişi sayısını göstermektedir.

2012 y1lında yürürlüğe giren 6331 Sayılı İş Sağlığı ve Güvenliği Kanunu spesifikliği dolayısıyla en önemli yasal düzenleme olma özelliğini taşımaktadır. Bu kanunun yürürlüğe girmesinden hemen sonra burada detaylarına değinilmeyecek olan pek çok yönetmeliğin yayınlandığı bilinmektedir. Tablo 1'de 2012 yılına kadar olan veriler incelenmesi tamamlanmış iş kazalarına karşıllı gelmektedir. 2012 yılından sonraki yıllarda ise bu veriler, yıl içerisinde bildirilen sayıları kapsamaktadır. Bu nedenle 2012 yılı öncesi ve sonrasındaki verilerde bir süreksizlik görülmektedir.

Ayrıca Tablo 1'de yer alan sürekli iş görmezlik bilgileri 2012 yllına kadar sürekli iş görmezlik başlığı altında açıklanan verileri kapsamaktadır. 2013 yılından itibaren bu bilgiler, ilgili yılda iş kazası veya meslek hastalığından dolayı gelir bağlanan kişi sayısı olarak açıklanmaya başlanmıştır.

Tablo 2'de Avrupa Birliği'ndeki bazı ülkelerin tarım, sanayi ve inşaat sektörlerinde (madencilik hariç) iş kazaları sonucu ölüm sayıları ve kaza sıklıkları verilmektedir [39].

Tablo 2'de yalnızca ölümle sonuçlanan iş kazası sayısının en çok olduğu Avrupa ülkelerine yer verilmiştir. Burada dikkat çeken en önemli husus Tablo 2'de verilen iş kazası sonucu ölüm sayıları tarım, sanayi ve inşaat sektörlerinin toplamını içermesidir. Avrupa İstatistik Ofisi (Eurostat) tarafından bu veriler tarım, sanayi ve inşaat sektörlerindeki toplam iş kazası sayılarını içerecek şekilde açıklandığından Tablo 2'de de bu şekilde yer verilmiştir. Örneğin Tablo 1'de 2018 yılında Türkiye'de iş kazası nedeniyle ölüm sayısı 1541 iken kaza sıklığ 1 
10,83; inşaat sektöründeki iş kazası nedeniyle ölüm sayısı 591 iken kaza sıklığının 36,91 olduğu görülmektedir. Tablo 2'de aynı yıl İtalya için açıklanan ölüm sayısının 440 kaza sıklığının ise 2,64 olduğu görülmektedir. Daha önce de belirtildiği gibi Tablo 2'deki sayılar tarım, sanayi ve inşaat sektörlerindeki iş kazası sayılarının toplamını içermektedir. Türkiye'nin diğer Avrupa ülkeleri arasındaki durumu değerlendirildiğinde çok kritik bir yere sahip olduğu anlaşılmaktadır.

Tablo 2 - Avrupa Birliği’ndeki bazı ülkelerdeki tarım, sanayi ve inşaat sektörlerinde (madencilik hariç) iş kazaları sonucu ölüm sayıları

\begin{tabular}{|c|c|c|c|c|c|c|c|c|c|c|c|}
\hline & \multicolumn{11}{|c|}{ Yıl (Kaza Sıklığı) } \\
\hline Ülke & 009 & 2010 & 2011 & 2012 & 2013 & 2014 & 2015 & 2016 & 2017 & 2018 & 2019 \\
\hline Almanya & $\begin{array}{c}454 \\
(1,31)\end{array}$ & $\begin{array}{c}536 \\
(1,52)\end{array}$ & $\begin{array}{c}469 \\
(1,45)\end{array}$ & $\begin{array}{c}473 \\
(1,45)\end{array}$ & $\begin{array}{c}425 \\
(1,26)\end{array}$ & $\begin{array}{c}475 \\
(1,40)\end{array}$ & $\begin{array}{c}425 \\
(1,23)\end{array}$ & $\begin{array}{c}387 \\
(1,11)\end{array}$ & $\begin{array}{c}404 \\
(1,14)\end{array}$ & $\begin{array}{c}369 \\
(1,00)\end{array}$ & $\begin{array}{c}391 \\
(1,04)\end{array}$ \\
\hline İspan & $\begin{array}{c}354 \\
(3,10)\end{array}$ & $\begin{array}{c}314 \\
(2,71)\end{array}$ & $\begin{array}{c}336 \\
(3,13)\end{array}$ & $\begin{array}{c}273 \\
(2,79)\end{array}$ & $\begin{array}{c}232 \\
(2,44)\end{array}$ & $\begin{array}{c}247 \\
(2,56)\end{array}$ & $\begin{array}{c}310 \\
(3,11)\end{array}$ & $\begin{array}{c}271 \\
(2,62)\end{array}$ & $\begin{array}{c}290 \\
(2,69)\end{array}$ & $\begin{array}{c}290 \\
(2,59)\end{array}$ & $\begin{array}{c}322 \\
(2,36)\end{array}$ \\
\hline Fransa & $\begin{array}{c}492 \\
(3,04)\end{array}$ & $\begin{array}{c}453 \\
(3,26)\end{array}$ & $\begin{array}{c}501 \\
(3,68)\end{array}$ & $\begin{array}{c}524 \\
(3,71)\end{array}$ & $\begin{array}{c}492 \\
(3,51)\end{array}$ & $\begin{array}{c}517 \\
(3,67)\end{array}$ & $\begin{array}{c}528 \\
(3,74)\end{array}$ & $\begin{array}{c}528 \\
(3,81)\end{array}$ & $\begin{array}{c}496 \\
(3,46)\end{array}$ & $\begin{array}{c}530 \\
(3,62)\end{array}$ & $\begin{array}{c}689 \\
(4,60)\end{array}$ \\
\hline İtalya & $\begin{array}{c}633 \\
(3,69)\end{array}$ & $\begin{array}{c}622 \\
(3,66)\end{array}$ & $\begin{array}{c}510 \\
(3,08)\end{array}$ & $\begin{array}{c}469 \\
(2,85)\end{array}$ & $\begin{array}{c}463 \\
(2,88)\end{array}$ & $\begin{array}{c}459 \\
(2,89)\end{array}$ & $\begin{array}{c}480 \\
(2,99)\end{array}$ & $\begin{array}{c}417 \\
(2,56)\end{array}$ & $\begin{array}{c}398 \\
(2,42)\end{array}$ & $\begin{array}{c}440 \\
(2,64)\end{array}$ & $\begin{array}{c}406 \\
(2,42)\end{array}$ \\
\hline Avus & $\begin{array}{c}153 \\
(5,80)\end{array}$ & $\begin{array}{c}158 \\
(5,35)\end{array}$ & $\begin{array}{c}106 \\
(3,75)\end{array}$ & $\begin{array}{c}137 \\
(4,50)\end{array}$ & $\begin{array}{c}130 \\
(4,31)\end{array}$ & $\begin{array}{c}119 \\
(4,02)\end{array}$ & $\begin{array}{c}125 \\
(4,23)\end{array}$ & $\begin{array}{c}100 \\
(3,81)\end{array}$ & $\begin{array}{c}90 \\
(3,41)\end{array}$ & $\begin{array}{c}120 \\
(3,90)\end{array}$ & $\begin{array}{c}93 \\
(3,03)\end{array}$ \\
\hline Polonya & $\begin{array}{c}334 \\
(4,79)\end{array}$ & $\begin{array}{c}366 \\
(4,02)\end{array}$ & $\begin{array}{c}344 \\
(2,82)\end{array}$ & $\begin{array}{c}303 \\
(2,56)\end{array}$ & $\begin{array}{c}227 \\
(1,94)\end{array}$ & $\begin{array}{c}225 \\
(1,90)\end{array}$ & $\begin{array}{c}266 \\
(2,20)\end{array}$ & $\begin{array}{c}198 \\
(1,60)\end{array}$ & $\begin{array}{c}235 \\
(2,42)\end{array}$ & $\begin{array}{c}183 \\
(1,89)\end{array}$ & $\begin{array}{c}149 \\
(1,15)\end{array}$ \\
\hline Portekiz & $\begin{array}{c}204 \\
(5,47)\end{array}$ & $\begin{array}{c}197 \\
(5,42)\end{array}$ & $\begin{array}{c}180 \\
(5,17)\end{array}$ & $\begin{array}{c}162 \\
(5,02)\end{array}$ & $\begin{array}{c}145 \\
(4,65)\end{array}$ & $\begin{array}{c}148 \\
(4,70)\end{array}$ & $\begin{array}{c}148 \\
(4,69)\end{array}$ & $\begin{array}{c}130 \\
(4,04)\end{array}$ & $\begin{array}{c}133 \\
(4,00)\end{array}$ & $\begin{array}{c}90 \\
(2,67)\end{array}$ & $\begin{array}{c}92 \\
(2,71)\end{array}$ \\
\hline Romanya & $\begin{array}{c}370 \\
(4,81)\end{array}$ & $\begin{array}{c}342 \\
(5,23)\end{array}$ & $\begin{array}{c}273 \\
(7,66)\end{array}$ & $\begin{array}{c}257 \\
(6,98)\end{array}$ & $\begin{array}{c}252 \\
(6,79)\end{array}$ & $\begin{array}{c}253 \\
(6,60)\end{array}$ & $\begin{array}{c}261 \\
(6,63)\end{array}$ & $\begin{array}{c}229 \\
(5,58)\end{array}$ & $\begin{array}{c}224 \\
(5,31)\end{array}$ & $\begin{array}{c}221 \\
(5,18)\end{array}$ & $\begin{array}{c}215 \\
(3,40)\end{array}$ \\
\hline $\begin{array}{l}\text { Birleşik } \\
\text { Krallık }\end{array}$ & $\begin{array}{c}133 \\
(0,73)\end{array}$ & $\begin{array}{c}158 \\
(0,90)\end{array}$ & $\begin{array}{c}172 \\
(0,95)\end{array}$ & $\begin{array}{c}149 \\
(0,80)\end{array}$ & $\begin{array}{c}235 \\
(1,26)\end{array}$ & $\begin{array}{c}207 \\
(1,10)\end{array}$ & $\begin{array}{c}226 \\
(1,15)\end{array}$ & $\begin{array}{c}222 \\
(1,11)\end{array}$ & $\begin{array}{c}248 \\
(1,22)\end{array}$ & $\begin{array}{c}227 \\
(1,12)\end{array}$ & $\begin{array}{c}\text { Mevcut } \\
\text { değil }\end{array}$ \\
\hline
\end{tabular}

Tablo 3’te Sosyal Güvenlik Kurumu verilerinden elde edilen 2019 yllı içerisinde iş kazası sonucu ölenlerin ekonomik faaliyet alanlarına göre sayıları görülmektedir. Tablo 3 detaylı bir şekilde incelendiğinde inşaat sektörünün yeri net bir şekilde görülebilmektedir. Diğer faaliyet gruplarına kıyasla iş kazalarında en çok ölümün inşaat sektöründe gerçekleştiği söylenebilmektedir. Tablo 3 yalnızca 2019 yılı verilerini içermektedir. Ancak burada detayları verilmeyen diğer yıllara ait veriler incelendiğinde de benzer durumların var olduğu görülmektedir. 
Tablo 3 - 2019 Yılı İş Kazaları Sonucu Ölümlerin İşyerinin Faaliyet Gruplarına Dă̆ılımı [40].

\begin{tabular}{|c|c|c|c|}
\hline Sektör & Faaliyet Grubu & $\begin{array}{l}\text { İş Kazası } \\
\text { Sonucu } \\
\text { Ölüm Sayısı }\end{array}$ & Oran $(\%)$ \\
\hline İnşaat & Bina İnşaatı & 207 & 18,05 \\
\hline Taşımacılık & $\begin{array}{l}\text { Kara taşımacılığı ve boru hattı } \\
\text { taşımacılığı }\end{array}$ & 184 & 16,04 \\
\hline İnşaat & Bina Dışı Yapıların İnşaatı & 105 & 9,15 \\
\hline İnşaat & Özel İnşaat Faaliyetleri & 56 & 4,88 \\
\hline Ticaret & $\begin{array}{l}\text { Toptan ticaret. motorlu kara taşıtları ve } \\
\text { motosikletler hariç }\end{array}$ & 34 & 2,96 \\
\hline Metal & $\begin{array}{l}\text { Makine ve teçhizat hariç. fabrikasyon } \\
\text { metal ürünleri imalatı }\end{array}$ & 31 & 2,70 \\
\hline Temizlik & $\begin{array}{l}\text { Binalar ve çevre düzenlemesi } \\
\text { faaliyetleri }\end{array}$ & 31 & 2,70 \\
\hline Maden & Diğer Madencilik ve Taşocakçılığ & 28 & 2,44 \\
\hline Ticaret & $\begin{array}{l}\text { Perakende ticaret ( Motorlu kara } \\
\text { taşıtları ve motosikletler hariç) }\end{array}$ & 28 & 2,44 \\
\hline Gida & Gıda ürünlerinin imalatı & 27 & 2,35 \\
\hline İmalat & $\begin{array}{l}\text { Diğer metalik olmayan mineral } \\
\text { ürünlerin imalatı }\end{array}$ & 24 & 2,09 \\
\hline Taşımacılık & $\begin{array}{l}\text { Taşımacılık için depolama ve } \\
\text { destekleyici faaliyetler }\end{array}$ & 24 & 2,09 \\
\hline Gida & Yiyecek ve içecek hizmeti faaliyetleri & 22 & 1,92 \\
\hline $\begin{array}{l}\text { Havalandırma } \\
\text { Sistemleri }\end{array}$ & $\begin{array}{l}\text { Elektrik gaz buhar ve havalandırma } \\
\text { sistemi üretim ve dağıtımı }\end{array}$ & 21 & 1,83 \\
\hline Tekstil & Tekstil ürünlerinin imalatı & 20 & 1,74 \\
\hline Metal & Ana metal sanayii & 19 & 1.66 \\
\hline Diğer Sektörler & $\begin{array}{l}\text { SGK verilerindeki diğer } 81 \text { adet } \\
\text { faaliyet grubuna ait sayılar }\end{array}$ & 286 & 27,93 \\
\hline \multicolumn{2}{|r|}{ Toplam } & 1147 & 100 \\
\hline
\end{tabular}

İnşaat sektörü, dinamik yapısından dolayı [6] çok sayıda faaliyet içermektedir. Her bir inşaat işi kendine özgü üretim aşamalarından ve faaliyetlerden oluşmaktadır. Bu nedenle çoğu zaman, çalışılan inşaat işine özgü güvenlik önlemi alınmasını gerektirmektedir. Proje bazlı üretimlerin gerçekleştirilmesi, işlerin yetiştirilmesi için zaman kısıtı bulunması, çok sayıda malzeme ve ekipman kullanımı gerektirmesi, iş gücünün çoğunluğunu vasıfsız işçilerin oluşturması gibi pek çok nedenden dolayı inşaat işleri çok sayıda değişkeni bünyesinde 
barındırmaktadır. $\mathrm{Bu}$ nedenle inşaat sektörünün dünyadaki en riskli sektör olduğunu söylemek mümkün olmaktadır [41, 42]. Yukarıda verilen tablolar incelendiğinde Türkiye'de de iş kazaları açısından en riskli sektörün inşaat sektörü olduğu anlaşılmaktadır.

Tablo 4 - Bilirkişi raporlarına göre iş kazalarının nedenleri [34]

\begin{tabular}{|l|c|c|c|c|c|c|}
\hline Nedenler (ICD-10 kodu) & Ölüm & \% & Yaralanma & \% & Toplam & $\%$ \\
\hline Düşmeler (W00-W19) & 426 & 54,1 & 191 & 52,9 & 617 & 53,7 \\
\hline $\begin{array}{l}\text { Fırlayan, düşen nesne çarpması } \\
\text { (bina göçmesi, çökmeler hariç) } \\
\text { (W20) }\end{array}$ & 102 & 12,9 & 50 & 13,9 & 152 & 13,2 \\
\hline Bina/ yapı kısmı çökmesi (W20) & 78 & 9,9 & 43 & 11,9 & 121 & 10,5 \\
\hline Elektriğe maruz kalma (W85-87) & 59 & 7,5 & 15 & 4,2 & 74 & 6,4 \\
\hline $\begin{array}{l}\text { Göçmeler (kazı sırasında veya } \\
\text { sonrasında) (W20) }\end{array}$ & 36 & 4,6 & 10 & 2,8 & 46 & 4,0 \\
\hline $\begin{array}{l}\text { Diğer tip kazalar (W25-31, W68- } \\
\text { 70, W73-74, X40-40) }\end{array}$ & 26 & 3,3 & 11 & 3,0 & 37 & 3,2 \\
\hline $\begin{array}{l}\text { Ağır ekipman kazaları (W24 ve } \\
\text { V09.0) }\end{array}$ & 21 & 2,7 & 5 & 1,4 & 26 & 2,3 \\
\hline $\begin{array}{l}\text { Ağır ekipman düşmeleri (W24 ve } \\
\text { V09) }\end{array}$ & 13 & 1,6 & 2 & 0,6 & 15 & 1,3 \\
\hline $\begin{array}{l}\text { Duman, ateş ve aleve maruz kalma } \\
\text { (X00-X09) ve patlama (W36, 40) }\end{array}$ & 12 & 1,5 & 11 & 3,0 & 23 & 2,0 \\
\hline $\begin{array}{l}\text { W23 Nesnelerin içinde veya } \\
\text { arasında sıkışma, ezilme }\end{array}$ & 11 & 1,4 & 4 & 1,1 & 15 & 1,3 \\
\hline $\begin{array}{l}\text { Şantiye içi trafik kazaları (W01- } \\
\text { 09) }\end{array}$ & 3 & 0,4 & 4 & 1,1 & 7 & 0,6 \\
\hline $\begin{array}{l}\text { Makine parçası arasına sıkısma/ } \\
\text { uzuv kaptırma (W23) }\end{array}$ & 1 & 0,1 & 15 & 4,2 & 16 & 1,4 \\
\hline Toplam & 788 & 361 & & 1.149 & \\
\hline
\end{tabular}

SGK tarafından her yıl bir önceki yıla ait iş kazası verileri ayrıntılı bir şekilde paylaşılmasına rağmen sektörlere göre iş kazası tipleri ayrı ayrı ilan edilmemektedir. Sektörlere göre iş kazası tiplerinin incelenmesi daha detaylı bir çalışma gerektirmektedir. İş kazalarına ilişkin detaylara ulaşmak için kaza raporlarının ve tutanaklarının incelenmesi, mahkeme kararlarına 
ulaşılması ve incelenmesi, kazanın gerçekleştiği firma ile iletişim sağlanarak bilgi alınması gibi zor ve zahmetli çalışma süreçleri gerekmektedir. Her ne kadar zaman içerisinde inşaat yöntemleri ve uygulamaları geliştirilmiş olsa bile kaza nedenlerinin özü aynı kalmaktadır [28]. Bu çalışma kapsamında da uygulamanın gerçekleştirilmesi için bir veri tabanı oluşturma firsatı bulunmadığından literatürdeki çalışmalardan yararlanılmıştır.

Bu çalışmada Gürcanlı ve Müngen (2013) [34] tarafindan incelenen 1117 adet bilirkişi raporunda yer alan, ölüm ve yaralanma ile sonuçlanan 1149 adet iş kazasına ait verilerden yararlanılmıştır. Gürcanlı ve Müngen (2013) [34] tarafindan incelenen kazalar kaza sonucuna, zamanına, ana sebeplerine, inşaat tipine, kazazedenin mesleğine, kaza anındaki faaliyetine ve kazadan sorumlu tarafa göre sınıflandırılmıştır. Kaza nedenleri hastalıkların ve sağlık sorunlarının uluslararası sınıflandırma sistemi ICD-10'a (International Statistical Classification of Diseases and Related Health Problems) göre sınıflandırılmıştır (Tablo 4). Hata ağacı uygulaması yapılırken Tablo 4 'teki iş kazası verilerinden yararlanılmıştır.

\section{YÖNTEM}

\subsection{Hata Ağacı Analizi}

Hata ağacı analizi yöntemi, 1962 yılında Amerika Birleşik Devletleri Hava Kuvvetlerine ait füze firlatma kontrol sisteminin güvenlik analizi için Bell Laboratuvarları tarafindan geliştirilmiştir [43]. Yöntem, 1966 yllından itibaren ticari bir şirket olan Boeing tarafından ticari uçakların geliştirilmesi için kullanılmaya başlanmıştır. İlerleyen yıllarda nükleer enerji sanayisinde, kimya, otomotiv, demiryolu taşımacıllğı, robotik gibi alanlarda kullanımı yaygınlaşmıştır [44]. Hemen hemen her sektörde kaza araştırmalarında kullanılmakta olan hata ağacı analizi, her tehlike durumunun varlığında uygulanmamaktadır, sadece kritik olan güvenlik tehlikeleri için uygulanmaktadır [44].

Hata ağacı analizi, sistem güvenliğinin ölçülmesinde kullanılan etkili bir yöntemdir. Bir sistemdeki istenmeyen bir durumun ortaya çıkma olasılı̆̆ının ve istenmeyen duruma neden olan kök olayların belirlenebildiği analitik bir teknik olarak tanımlanmaktadır [45, 46]. Hata ağacı, istenmeyen olayın meydana gelmesine neden olabilecek çeşitli paralel ve sıralı olay kombinasyonlarının ağaç şeklinde grafiksel olarak ifade edildiği modeldir [45, 46]. Hata ağacı analizi ile tümdengelimsel bir yaklaşım yapılmaktadır. Tümdengelimli sistem analizinde, sistemde bir hatanın var olduğu varsayılarak bu hataya neden olan kök nedenler araştırılmaktadır. $\mathrm{Bu}$ nedenle bu yaklaşım "Sherlock Holmes" yaklaşımı olarak da adlandırılmaktadır [45]. Hata ağacı analizinin adımları Şekil 1'de görülmektedir.

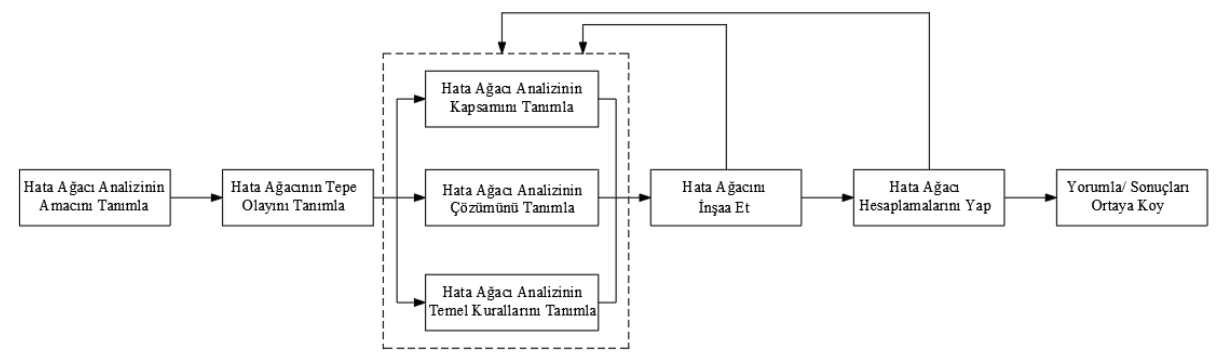

Şekil 1 - Hata ağacı analizi adımları [45] 
Hata ağacı analizinde ilk olarak amaç belirlenmektedir. Daha sonra bu amaca bağlı olarak sistemin tepe olayı belirlenmektedir. Tepe olay genellikle sistemdeki istenmeyen olayı ifade etmektedir. Tepe olaya neden olabilecek sebepler belirlenerek bu sebeplerin hem birbirleriyle hem de tepe olay ile olan ilişkisi mantık kapıları aracılığıyla gösterilerek hata ağacı yapısı oluşturulmaktadır. Belirlenen sebeplerin varsa alt sebepleri de belirlenerek mantık kapıları ile birbirine bağlanmaktadır. Sistemin tepe olayının oluşmasında etkili olabilecek bütün temel olaylar belirlenene kadar ağaç yapısı oluşturulmaya devam edilmektedir. Temel olay, oluşması kendisinden başka bir sebebe bağlı olmayan olayı ifade etmektedir. Sistemdeki bütün temel olayların belirlenmesiyle hata ağacı yapısı tamamlanmaktadır. Hata ağacı hesaplamaları aşağıdan yukarıya doğru yapılmaktadır. Oluşturulan ağaç yapısı içerisindeki küçük ağaç yapıları minimum kesme kümeleri (minimal cut sets) olarak adlandırılmaktadır.

Bir hata ağacı oluşturulurken çeşitli sembollerden yararlanılmaktadır. Tablo 5 'te hata ağacı oluşturulurken kullanılan semboller gösterilmektedir.

VE ve VEYA kapısı olmak üzere iki temel hata ağacı kapısı bulunmaktadır. Diğer tüm kapılar bu iki temel kapının özel durumlarını ifade etmektedir. Bu çalışma kapsamında da VE ve VEYA mantık kapıları kullanılarak hata ağacı yapısı oluşturulmuştur.

Tablo 5 - Hata ăgacı sembolleri [45-47]

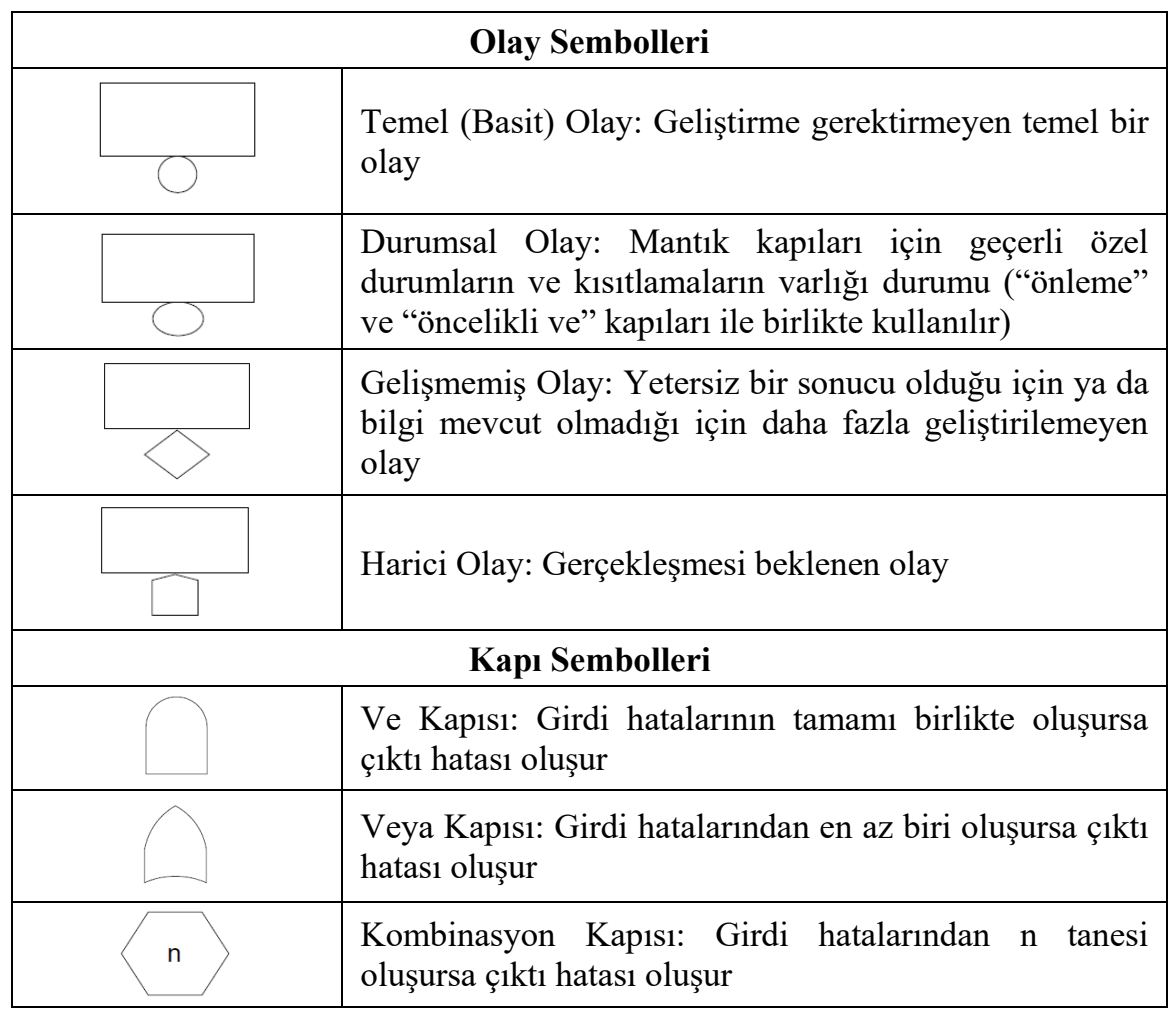


Tablo 5 - Hata ăgacı sembolleri [45-47]

\begin{tabular}{|l|l|}
\hline & $\begin{array}{l}\text { Kapı Sembolleri } \\
\text { Özel Veya Kapısı: Girdi hatalarından özel olarak biri } \\
\text { oluşursa çıtı hatası oluşur }\end{array}$ \\
\hline & $\begin{array}{l}\text { Öncelikli Ve Kapısı: Tüm girdi hataları oluşursa çıktı } \\
\text { hatası oluşur }\end{array}$ \\
\hline & $\begin{array}{l}\text { Önleme Kapısı: Durumsal olayın girdi hatası oluşursa } \\
\text { çıtı hatası oluşur }\end{array}$ \\
\hline & $\begin{array}{l}\text { İçeri Transfer: Ağacın başka bir yerde (örneğin başka bir } \\
\text { sayfada) daha da geliştirildiğini gösterir. }\end{array}$ \\
\hline & $\begin{array}{l}\text { Dişarı Transfer: Ağacin bu bölümünün içeri transfer } \\
\text { bölümüne eklenmesi gerektiğini gösterir. }\end{array}$ \\
\hline
\end{tabular}

Hata ağacı analizi hem nitel hem de nicel bir analizdir. Nicel analiz aşamasında hataların olasılık değerleri belirlenerek mantık kapıları arasındaki yayılma tespit edilmektedir. Nitel analiz aşamasında ise minimum kesme kümesi değerlendirmesi yapılmaktadır. Uygulama yapılırken Boolean matematiği kullanılmaktadır. Boolean matematiği kuralları Tablo 6'da verilmiştir.

Tablo 6 - Boolean Matematiği Kuralları [45, 48]

\begin{tabular}{|c|c|}
\hline Tanım & Kural \\
\hline Değişebilirlik (Commutative)Yasası & $\begin{array}{l}\text { 1a. } X \cdot Y=Y \cdot X \\
\text { 1b. } X+Y=Y+X\end{array}$ \\
\hline Birleşme (Associative) Yasası & $\begin{array}{l}\text { 2a. } X \cdot(Y \cdot Z)=(X \cdot Y) \cdot Z \\
\text { 2b. } X+(Y+Z)=(X+Y)+Z\end{array}$ \\
\hline Dağılma (Distributive) Yasası & $\begin{array}{c}\text { 3a. } X \cdot(Y+Z)=X \cdot Y+X \cdot Z \\
X \cdot(Y+Z)=X \cdot Y+X \cdot Z \\
\text { 3b. } X+Y \cdot Z=(X+Y) \cdot(X+Z)\end{array}$ \\
\hline Özdeşlik (Idempotent) Yasası & $\begin{array}{l}\text { 4a. } X \cdot X=X \\
\text { 4b. } X+X=X\end{array}$ \\
\hline Soğurma (Absorption) Yasası & $\begin{array}{l}\text { 5a. } X \cdot(X+Y)=X \\
5 \text { b. } X+X \cdot Y=X\end{array}$ \\
\hline de Morgan's Teoremi & $\begin{array}{l}\text { 6a. }(X \cdot Y)^{\prime}=X^{\prime}+Y^{\prime} \\
\text { 6b. }(X+Y)^{\prime}=X^{\prime} \bullet Y^{\prime}\end{array}$ \\
\hline
\end{tabular}

Bir hata ağacı analizinde tepe olayın olasılığını hesaplamak için Tablo 6'da verilen kurallardan yararlanılmaktadır. Tepe olayın olasılığını hesaplamak için hata ağacındaki her bir temel olayın olasılığının hesaplanması gerekmektedir. Temel olayın olasılıkları Boolean matematiği kullanılarak tepe olaya yayılmaktadır. Tepe olayın olasılığı aşağıdaki gibi belirlenmektedir: 


$$
\begin{aligned}
& \mathrm{P}(\text { Tepe })=\sum \mathrm{P}\left(\mathrm{M}_{\mathrm{i}}\right) \\
& \mathrm{P}\left(\mathrm{M}_{\mathrm{i}}\right)=\mathrm{P}\left(\mathrm{TO}_{1}\right) \mathrm{P}\left(\mathrm{TO}_{2}\right) \ldots \mathrm{P}\left(\mathrm{TO}_{\mathrm{k}}\right)
\end{aligned}
$$

Burada P olasıllığ ; Tepe, tepe olayı; $\mathrm{M}_{\mathrm{i}}$, belirli bir minimum kesme kümesini; $\mathrm{TO}$, temel olayı; $\mathrm{k}$, minimum kesme kümesi sayısını ifade etmektedir.

Aşağıda hata ağacı analizi basit bir örnek üzerinde gösterilmiştir (Şekil 2).

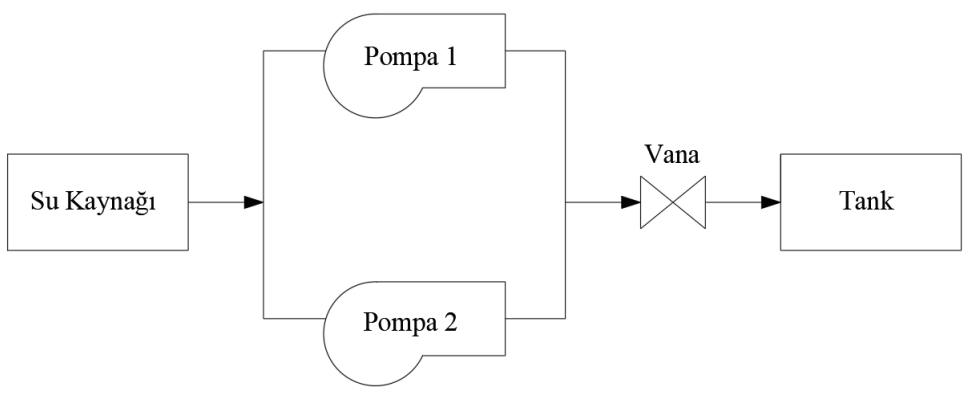

Şekil 2 - Su kaynă̆l sistemi örneği [45]

Şekil 2'de su kaynağından tanka Pompa 1, Pompa 2 ve vana aracıllğıyla su akış1 gerçekleşmektedir. $\mathrm{Bu}$ sistemde istenmeyen olay, su kaynağından tanka su akışının gerçekleşmemesidir. $\mathrm{Bu}$ durumda tanka su akışının olmaması sistemin tepe olayı olacaktır. Tepe olayın ortaya çıkmasının sebepleri Pompa 1'in ve Pompa 2'nin çalışmaması veya vananın kapalı olması durumlarıdır. Pompa 1 ve Pompa 2'nin çalışmama durumu VE mantık kapısı ile vananın kapalı olması ise VEYA mantık kapısı ile modellenerek hata ağacı yapısı oluşturulabilir. Bu sisteme ait hata ağacı yapısı Şekil 3 'te gösterilmektedir.

Şekil 3'te T, tepe olaydır ve tanka su akışının olmamasını ifade etmektedir. T'nin gerçekleşmesi için i) Vana kapalı olmalıdır. Şekil 3'te C ile gösterilen bu olay temel bir olaydır ve gerçekleşmesi için başka bir olayın varlığı gerekmemektedir. ii) Pompa 1'in (A) ve Pompa 2'nin (B) çalışmaması gerekmektedir. Bu durumda A ve B'nin çalışmaması durumu VE mantık kapısı ile ilişkilendirilmiştir. $\mathrm{E}_{1}$, A ve $\mathrm{B}$ olaylarının oluşturduğu yapı kendi içinde küçük bir hata ağacı yapısıdır ve Şekil 3'teki sistemin tamamına bakıldığında bir minimum kesme kümesini temsil etmektedir. $\mathrm{E}_{1}$, bu minimum kesme kümesinin tepe olayıdır. Şekil 3'teki sistemde, $E_{1}$ veya C'nin varlığı durumunda da $\mathrm{T}$ tepe olayı ortaya çıkacaktır.

Şekil 3'te verilen hata ağacı yapısının temel olayı T'nin olasılığı Eşitlik 2 ve Eşitlik 3'ten yararlanılarak hesaplanabilmektedir. T'nin oluşması için C VEYA E 1 'in oluşması gerekir. VEYA kapısının Boolean eşdeğeri "+" sembolüdür. Bu kapıya bağlı bir veya daha fazla olayın gerçekleşmesi durumunda kapı üzerindeki olay gerçekleşmektedir. $\mathrm{Bu}$ durum $\mathrm{T}=\mathrm{C}+$ $\mathrm{E}_{1}$ olarak ifade edilir. $\mathrm{E}_{1}$ 'in tepe olay olduğu minimum kesme kümesinin oluşması için de $\mathrm{A}$ VE B'nin oluşması gerekir. VE kapısının Boolean eşdeğeri “॰” sembolüdür. Bu kapıya bağglı olayların tümünün gerçekleşmesi durumunda kapı üzerindeki olay meydana gelmektedir. $\mathrm{Bu}$ durumda $E_{1}=A \cdot B$ olarak ifade edilir. Sonuç olarak $T=C+A \cdot B$ olacaktır. 


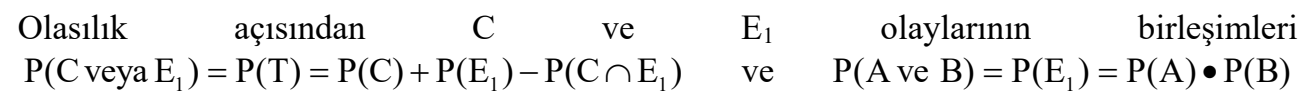
olarak ifade edilecektir.

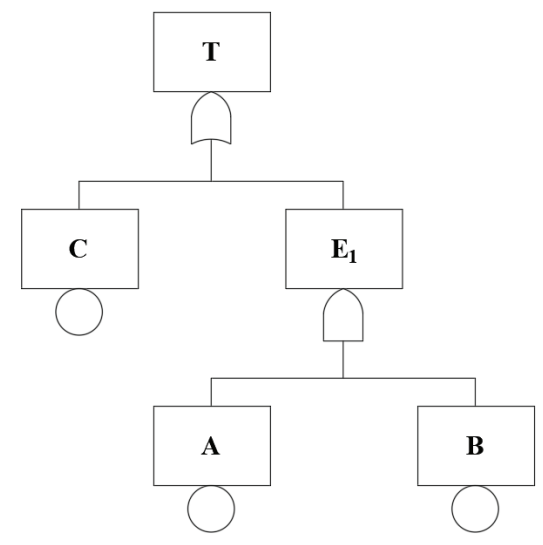

Şekil 3 - Su kaynăğ sistemi örneğine ait hata ağacı yapısı

\subsection{Hata Ağacı Analizinin Probleme Uygulanması}

Önceki bölümlerde belirtildiği gibi bu çalışma kapsamında hata ağacının uygulaması gerçekleştirilirken Gürcanlı ve Müngen (2013) [34] tarafından sınıflandırılan iş kazası verilerinden yararlanılmıştır. İlgili çalışma kapsamında incelenen iş kazalarından düşmelerin sebepleri detaylı olarak incelenerek bir analiz gerçekleştirilmiştir. Tepe olayın iş kazası olarak ele alındığı bu çalışma kapsamında, diğer iş kazası tiplerinin kök nedenleri belirlenirken tepe olaya sebep olan temel olayların belirlenebilmesi için 5 neden analizinden yararlanılmıştır. Böylece detaylarına ulaşılamayan diğer kaza tiplerinin kök sebepleri belirlenmiştir. 5 neden analizi ile elde edilen kök sebepler, temel olay ve gelişmemiş olaylar olarak belirlenmiştir. Yeterli bilgiye sahip olunmaması nedeniyle daha fazla geliştirilemeyen olaylar hata ağacı yapısı içerisinde gelişmemiş olaylar olarak gösterilmiştir.

5 neden analizi problemlerin kök nedenlerinin bulunmasında kullanılan bir yöntemdir [49]. Bir sorunun gerçek nedeninin net olmadığı durumlarda kullanılmaktadır. 5 neden analizi yapılırken ilk olarak problem tanımlanır. Bu probleme sebep olan nedenler yazılır. Nedenlerin neden ortaya çıktığı cevaplanır. Problemin ortaya çıkmasına sebep olan esas neden bulununcaya kadar "neden?" sorusu sorulmaya devam edilir [50]. "Neden?" sorusu bazı durumlarda 5 defadan daha az sorulabileceği gibi daha fazla da sorulabilir. Burada amaç kök neden analizi ile kazaya neden olan kök nedenlerin bulunmasını sağlayarak kazaları mümkünse önlemek veya azaltmaktır.

Şekil 4'te elektriğe maruz kalma iş kazası tipinin kök nedenlerini bulmada 5 neden analizi uygulaması gösterilmiştir. Bu çalışma kapsamında ele alınan iş kazalarının kök nedenlerini ayrıntılı inceleme firsatı bulunmadığından 5 neden analizini kullanma yoluna gidilmiştir. Şekil 4'te gösterilen yöntem kök nedenlerine ulaşılmak istenen diğer iş kazası tipleri için de uygulanarak Tablo 7 oluşturulmuştur. 


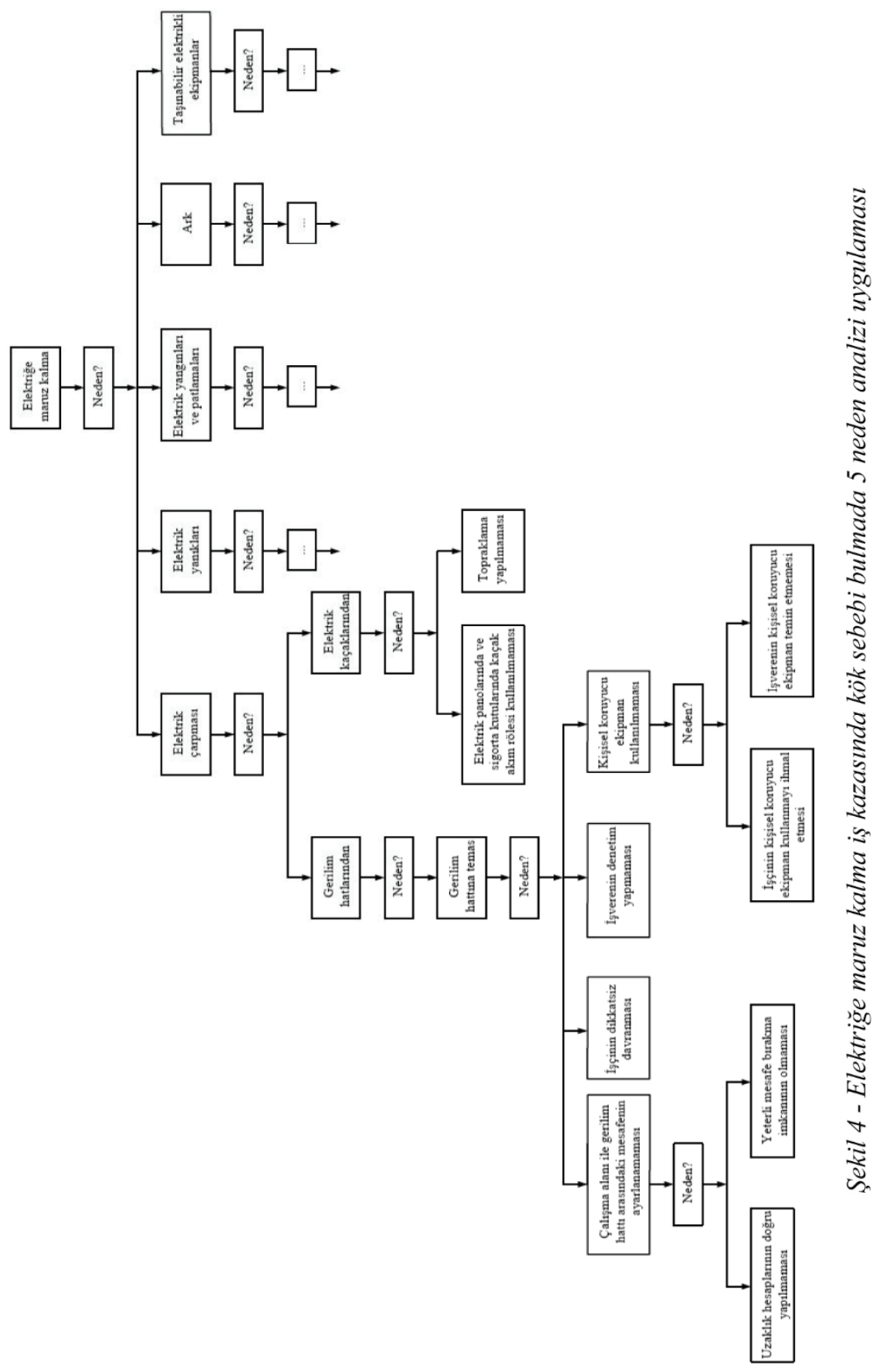


Şerife AK, İsmail ZORLUER

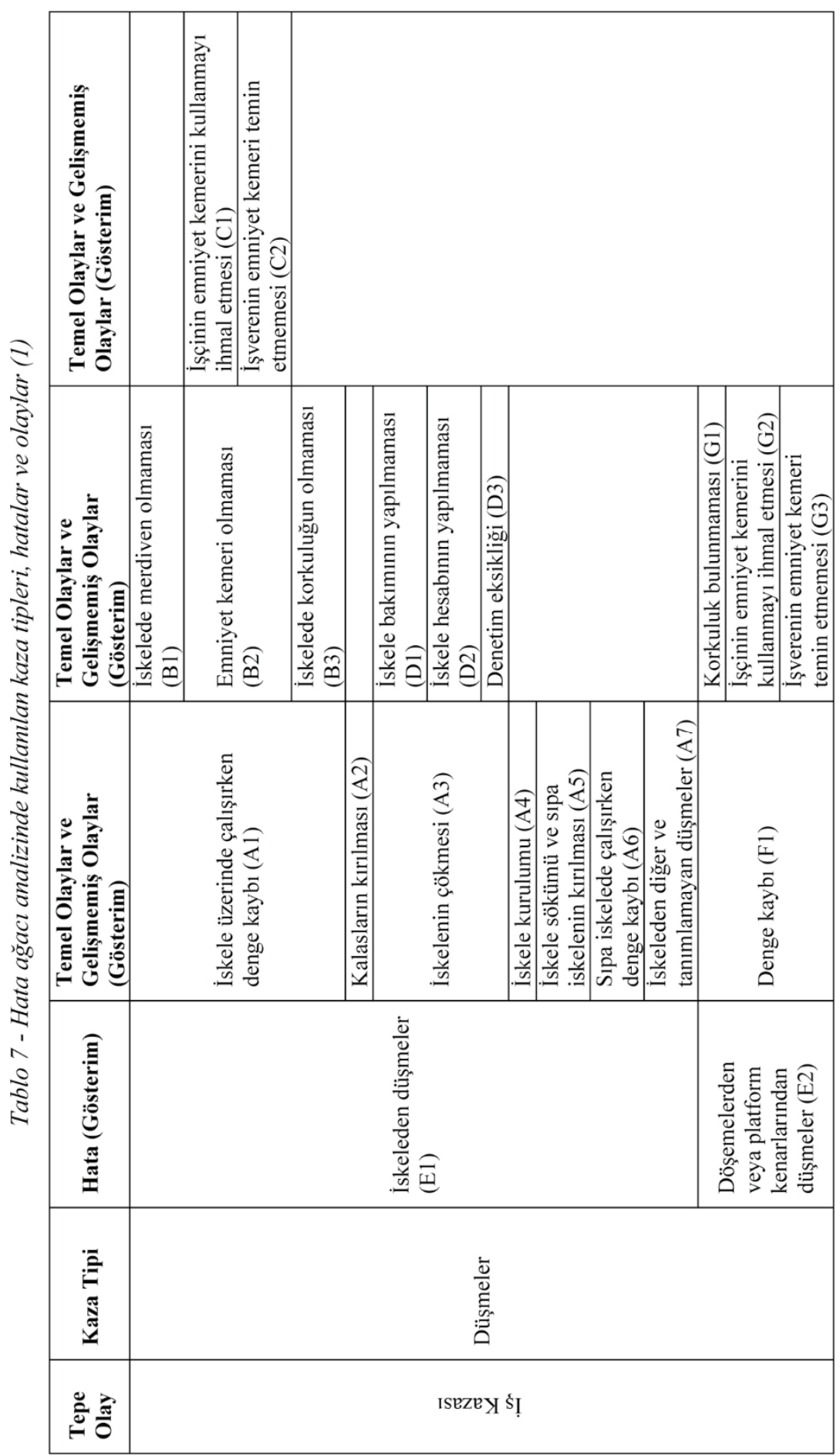




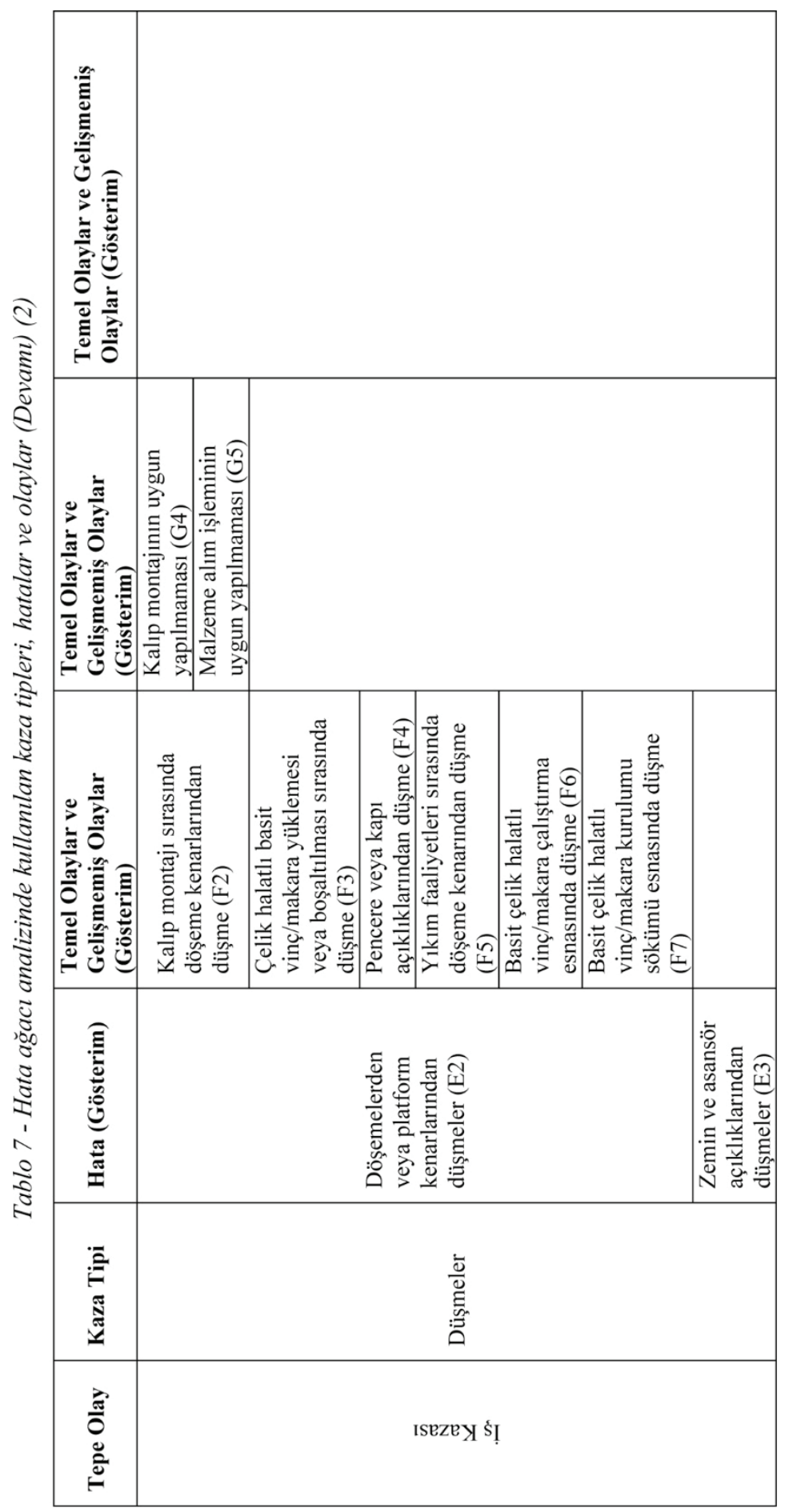


Şerife AK, İsmail ZORLUER

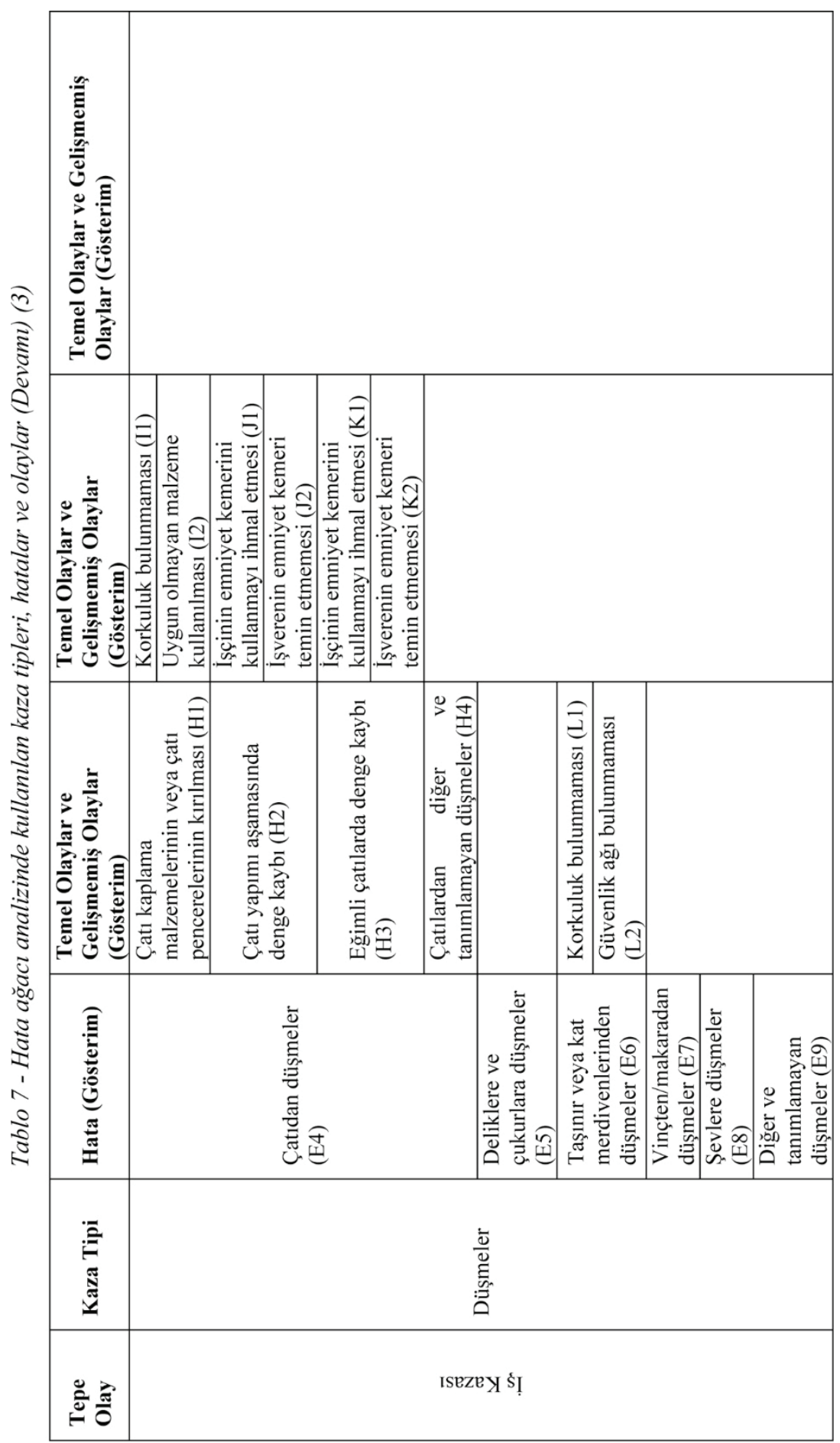




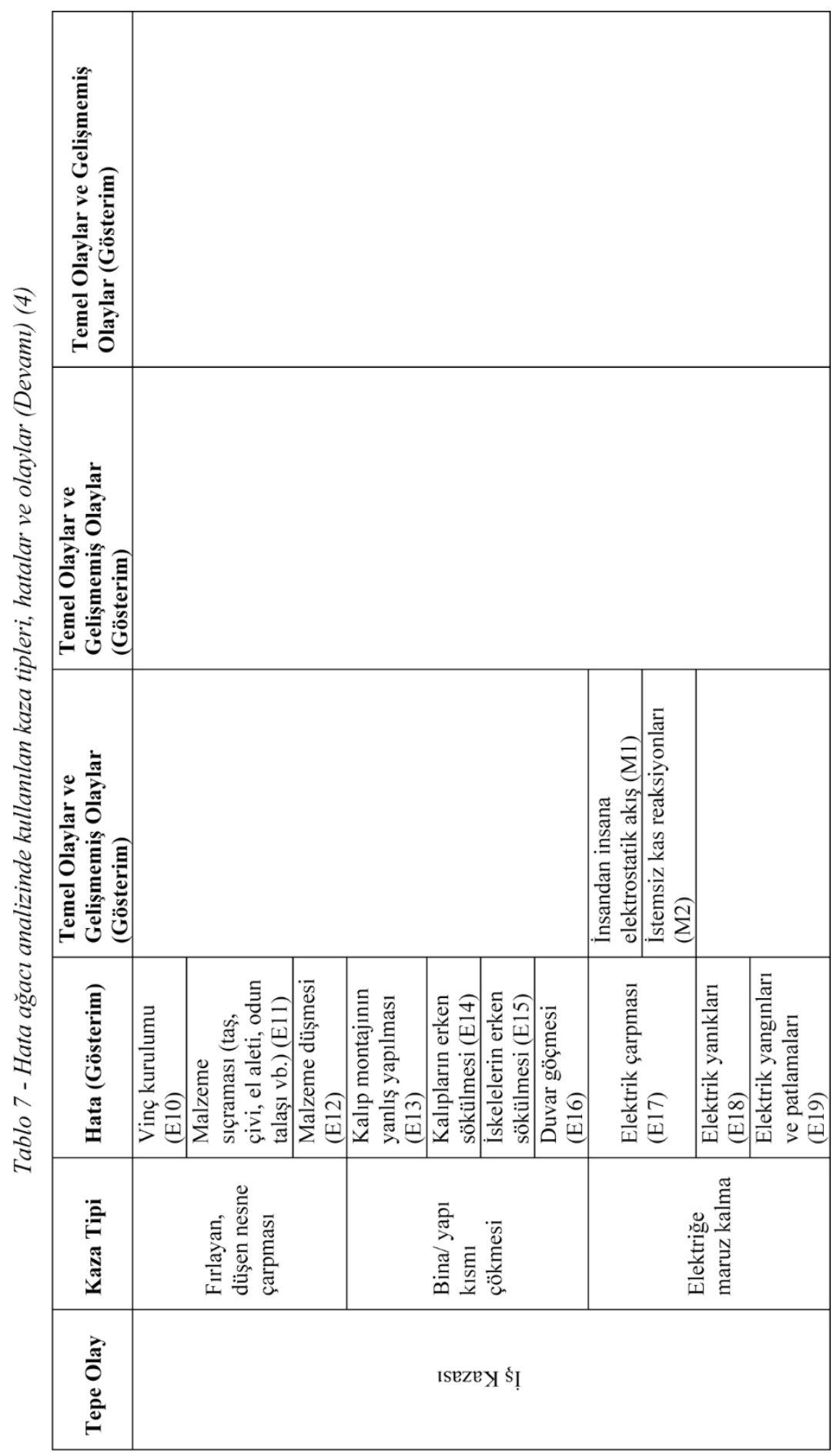


Şerife AK, İsmail ZORLUER

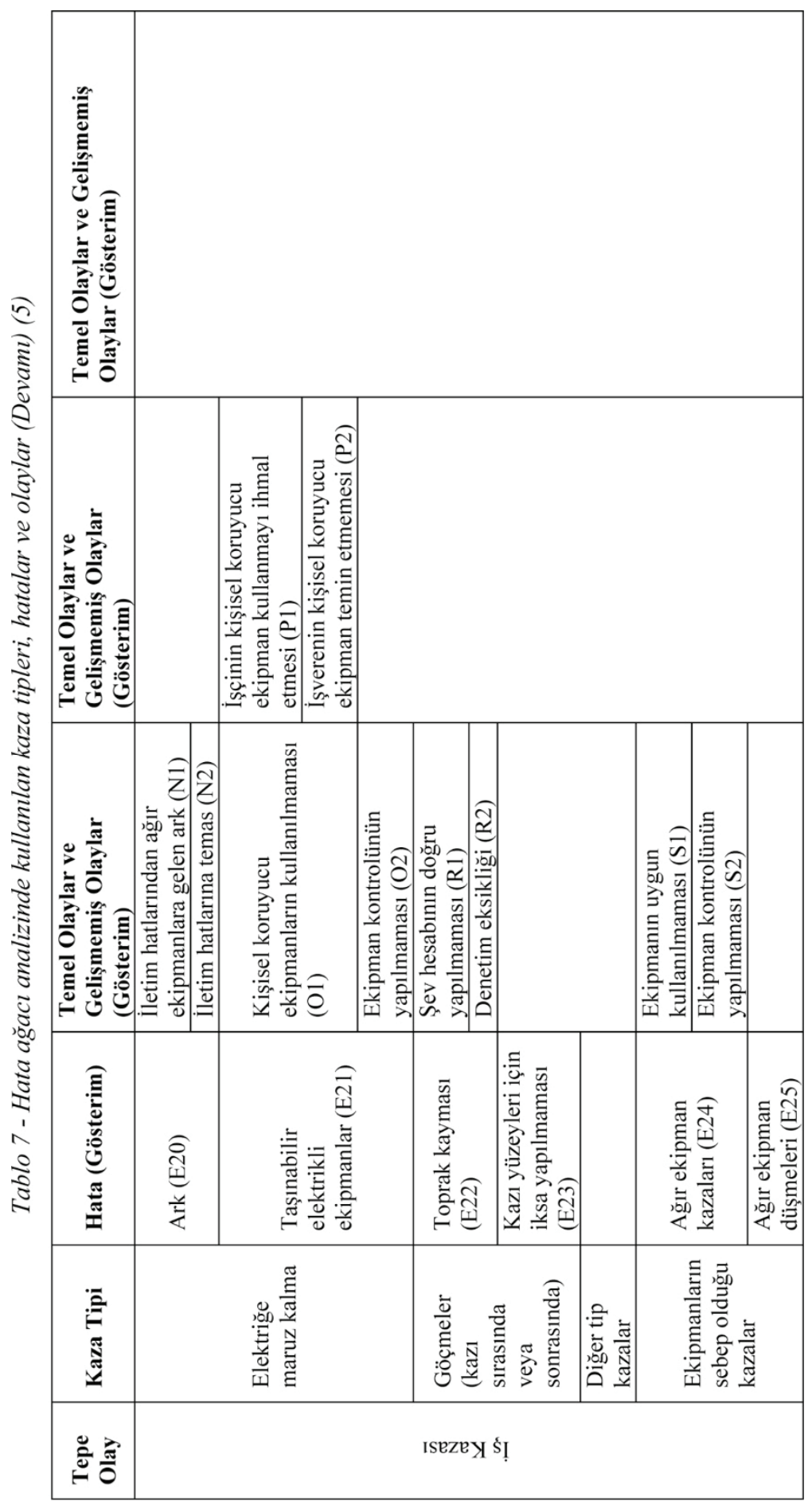




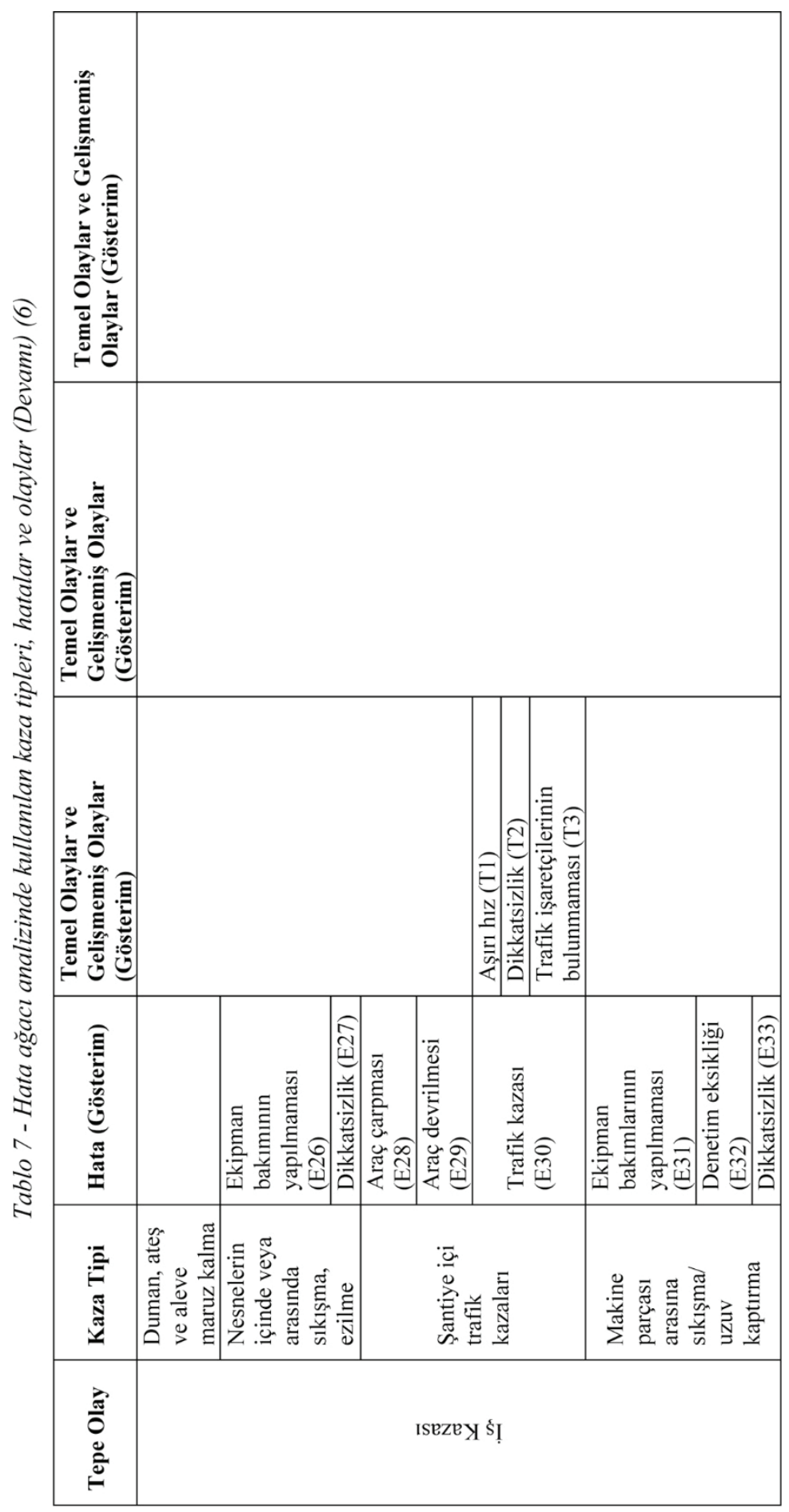


Hata ağacı yapısını oluştururken Tablo 7'de verilen kaza tipleri, hatalar ve olaylardan yararlanılmıştır. Tablo 4'te verilen ölüm ve yaralanma oranları ile Şekil 5'te verilen olasılık ölçeğinden yararlanılarak temel olayların ve gelişmemiş olayların olasılık değerleri, hata ağacı analizinde kullanılan yazılıma girilmiştir.

\begin{aligned} & \multicolumn{2}{c}{ Olasılık Ölçeği } \\ & 10 'da 1 S1k \\ & 100 'de 1 Muhtemel \\ & 1000 'de 1 Ara Sura \\ & 10000 'de 1 Çok Az \\ & \hline 100000 'de 1 Muhtemel Olmayan \\ & \hline 1000000 'da 1 Oldukça Az \end{aligned}

Şekil 5 - Olasıllk Ölçeği [51]

Yazılım aracılığıyla oluşturulan hata ağacındaki minimum kesme kümelerinin ve tepe olayın olasılık değerleri hesaplanmıştır. Bu değerlerin hesaplanmasında yazılım, önceki bölümlerde detaylarına değinilen Boolean matematiğinden yararlanmaktadır.

Tablo 7'deki bilgiler kullanılarak oluşturulan hata ağacı Şekil 6'da, minimum kesme kümeleri ise sırasıyla Şekil 7, Şekil 8, Şekil 9 ve Şekil 10'da görülmektedir. Gerçekleştirilen analiz sonucunda hesaplanan hata olasılığı değerleri de şekiller üzerinde görülmektedir. Tepe olayı iş kazası olan hata ağacının minimum kesme kümelerini Tablo 7'deki hata, temel ve gelişmemiş olaylar oluşturmaktadır.

Yapılan hesaplamalar sonucunda tepe olay olan iş kazasının olasılık değeri 0,3071 olarak hesaplanmıştır. Minimum kesme kümleri ayrı ayrı incelendiğinde en yüksek hata olasılığı değerine düşmelerin sahip olduğu görülmektedir. Daha sonra sirasıyla ekipmanların sebep olduğu kazalar; diğer tip kazalar; duman, ateş ve aleve maruz kalma; şantiye içi trafik kazaları; fırlayan, düşen nesne çarpması; nesnelerin içinde veya arasında sıkışma, ezilme; göçmeler (kazı sırasında veya sonrasında); bina/ yapı kısmı çökmesi; makine parçası arasına sıkışma/ uzuv kaptırma; elektriğe maruz kalma kaza tipleri gelmektedir. Daha öncede belirtildiği gibi hata ağacı analizi hem nitel hem de nicel bir analizdir. Nitel analiz ile iş kazası sonucu ölüme veya yaralanmaya neden olan minimum kesme kümelerinin belirlenmesi sağlanmıştır. Nicel analiz ile de minimum kesme kümelerinin hata olasılığ değerlerinden yola çıkarak tepe olayın hata olasılığg değerine ulaşılmıştır.

Her bir minimum kesme kümesi tepe olayın ortaya çıkmasına neden olan temel ve gelişmemiş olayları içermektedir. Tepe olayın ortaya çıkmasını engellemek için temel ve gelişememiş olayların engellenmesi gerekmektedir. Minimum kesme kümelerindeki temel ve gelişmemiş olaylar aracılığıyla tepe olayı ortaya çıkaran nedenler için kritik önem faktörü (critical importance factor- CIF) hesaplanabilmektedir. Literatürde Fussel-Vesely önemi olarak adlandırılan kritik önem faktörü hata ağacı analizinde sık başvurulan genel önem ölçütüdür [52]. Kritik önem faktörü, belirli bir olayla ilişkili riski, yani olayın meydana gelmesinin sistem hatasına ne kadar katkıda bulunduğunu göstermektedir. 


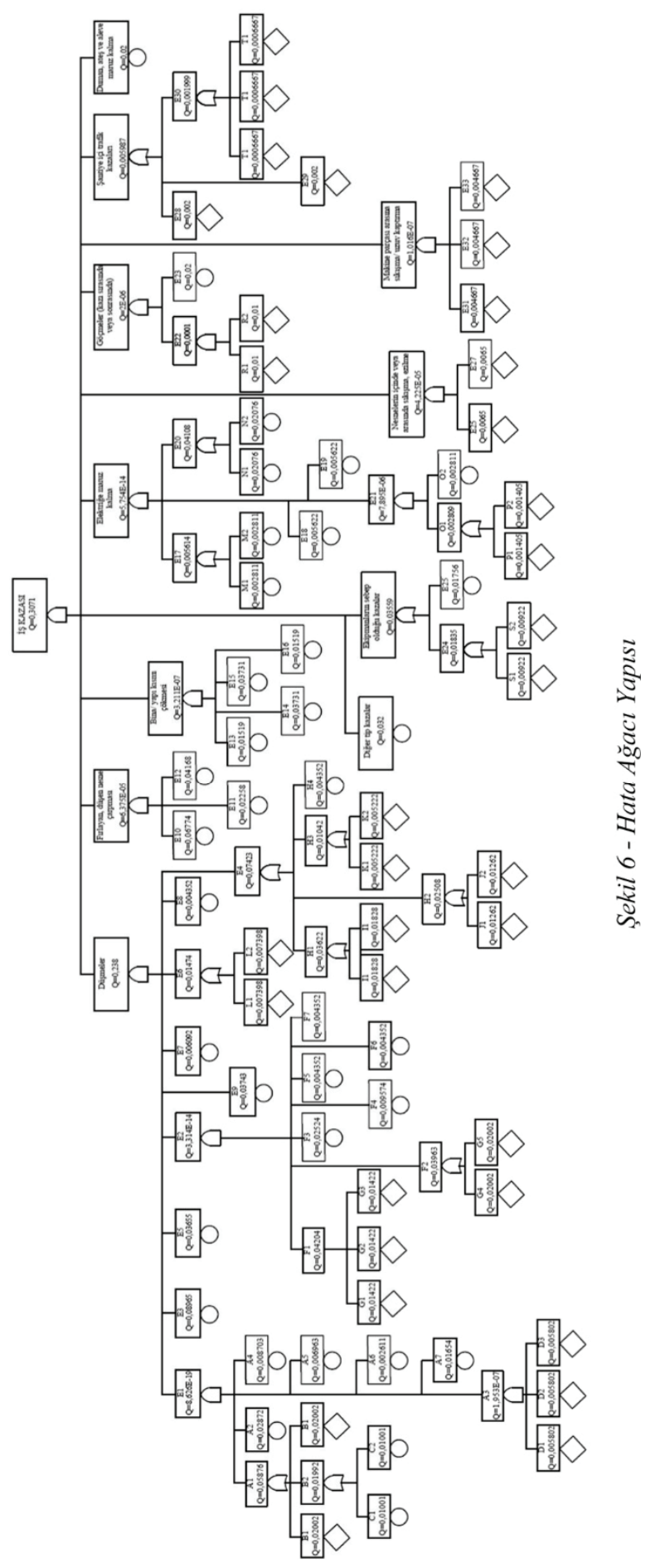


Şerife AK, İsmail ZORLUER

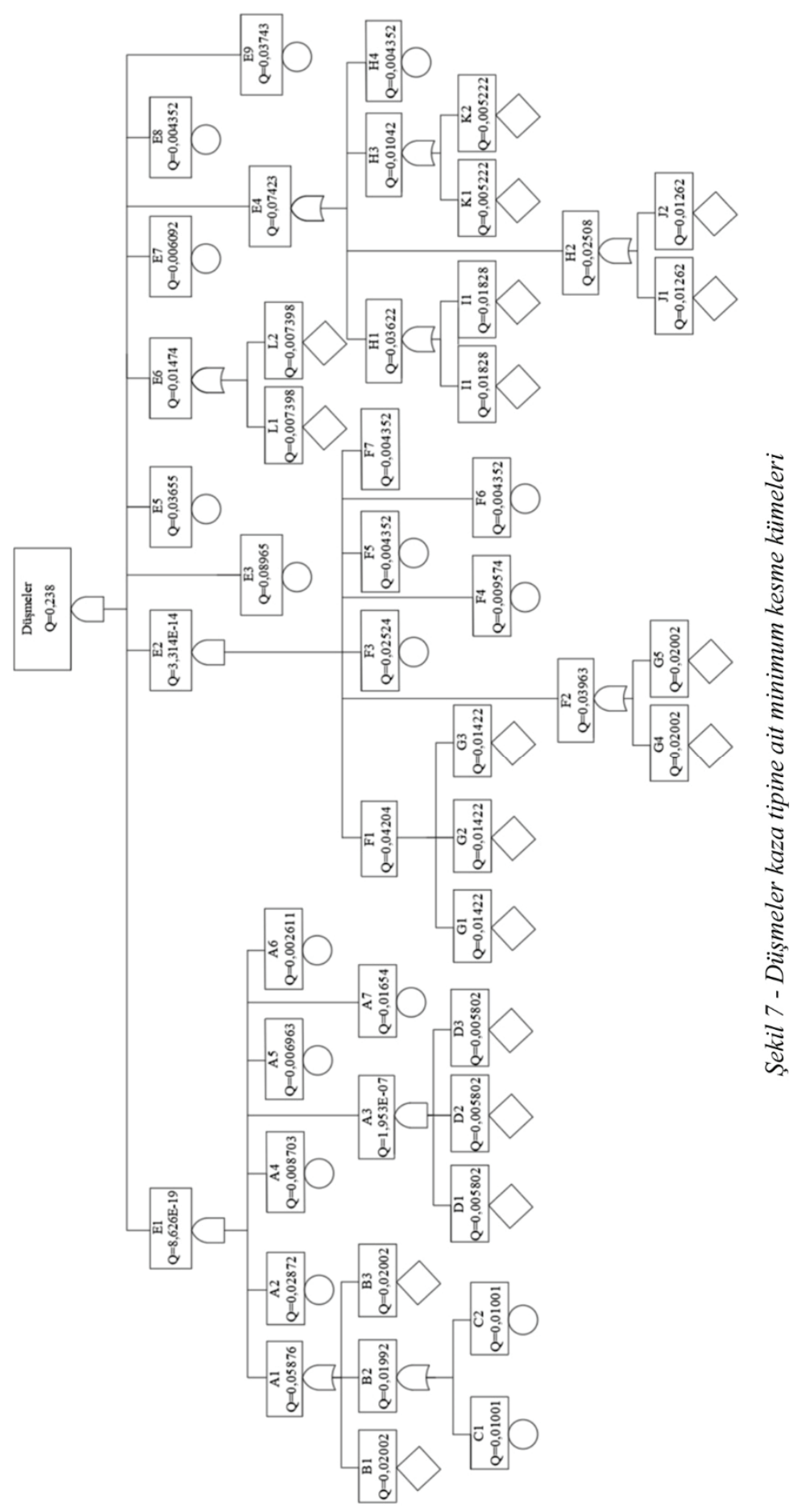


Hata ağacının analiz edilmesiyle elde edilen Fussel-Vesely önem ölçütüne göre hataların önem dereceleri Tablo 8'de verilmiştir.

Tablo 8 - Tepe olaya neden olan olayların Fussel-Vesely önem ölçütüne göre kritik önem faktörleri

\begin{tabular}{|l|l|l|l|l|l|}
\hline HATA & $\begin{array}{l}\text { Kritik } \\
\text { Önem } \\
\text { Faktörü }\end{array}$ & HATA & $\begin{array}{l}\text { Kritik } \\
\text { Önem } \\
\text { Faktörü }\end{array}$ & HATA & $\begin{array}{l}\text { Kritik } \\
\text { Onem } \\
\text { Faktörü }\end{array}$ \\
\hline E3 & 0,222207 & E10 & 0,00014387 & P2 & $6,48781 \mathrm{E}-14$ \\
\hline E9 & 0,0877345 & E12 & 0,00014387 & M1 & $6,48324 \mathrm{E}-14$ \\
\hline E5 & 0,0856152 & E11 & 0,00014387 & M2 & $6,48324 \mathrm{E}-14$ \\
\hline $\begin{array}{l}\text { Diğer tip } \\
\text { kazalar }\end{array}$ & 0,0745964 & E26 & $9,53429 \mathrm{E}-05$ & N1 & $6,42428 \mathrm{E}-14$ \\
\hline $\begin{array}{l}\text { Duman, ates } \\
\text { ve aleve maruz } \\
\text { kalma }\end{array}$ & 0,0460519 & E27 & $9,53429 \mathrm{E}-05$ & N2 & $6,42428 \mathrm{E}-14$ \\
\hline I1 & 0,042011 & E23 & $4,51309 \mathrm{E}-06$ & G4 & $3,70703 \mathrm{E}-14$ \\
\hline I2 & 0,042011 & R1 & $4,51309 \mathrm{E}-06$ & G5 & $3,70703 \mathrm{E}-14$ \\
\hline E25 & 0,0403354 & R2 & $4,51309 \mathrm{E}-06$ & G1 & $2,46085 \mathrm{E}-14$ \\
\hline J1 & 0,0288414 & E14 & $7,24568 \mathrm{E}-07$ & G2 & $2,46083 \mathrm{E}-14$ \\
\hline J2 & 0,0288414 & E15 & $7,24568 \mathrm{E}-07$ & G3 & $2,46081 \mathrm{E}-14$ \\
\hline S1 & 0,0209978 & E13 & $7,24568 \mathrm{E}-07$ & A2 & $2,1357 \mathrm{E}-18$ \\
\hline S2 & 0,0209978 & E16 & $7,24568 \mathrm{E}-07$ & D1 & $1,9473 \mathrm{E}-18$ \\
\hline L1 & 0,0168183 & E31 & $2,29332 \mathrm{E}-07$ & A7 & $1,94645 \mathrm{E}-18$ \\
\hline L2 & 0,0168183 & E32 & $2,29332 \mathrm{E}-07$ & A4 & $1,94645 \mathrm{E}-18$ \\
\hline E7 & 0,0138311 & E33 & $2,29332 \mathrm{E}-07$ & A5 & $1,94645 \mathrm{E}-18$ \\
\hline K1 & 0,0118456 & E18 & $1,29847 \mathrm{E}-13$ & D2 & $1,94645 \mathrm{E}-18$ \\
\hline K2 & 0,0118456 & E19 & $1,29847 \mathrm{E}-13$ & D3 & $1,94645 \mathrm{E}-18$ \\
\hline H4 & 0,0098634 & O2 & $1,29847 \mathrm{E}-13$ & A6 & $1,94645 \mathrm{E}-18$ \\
\hline E8 & 0,0098634 & F3 & $7,48976 \mathrm{E}-14$ & B1 & 0 \\
\hline E28 & 0,00452213 & F4 & $7,48976 \mathrm{E}-14$ & B3 & 0 \\
\hline E29 & 0,00452213 & F5 & $7,48976 \mathrm{E}-14$ & C1 & 0 \\
\hline T1 & 0,00150537 & F6 & $7,48976 \mathrm{E}-14$ & C2 & 0 \\
\hline T2 & 0,00150537 & F7 & $7,48976 \mathrm{E}-14$ & & \\
\hline T3 & 0,00150537 & P1 & $6,48781 \mathrm{E}-14$ & & \\
\hline & & & & & \\
\hline
\end{tabular}


Kritik önem faktörleri aşağıdaki eşitlik aracılığıyla hesaplanabilmektedir.

$$
\mathrm{CIF}_{\mathrm{x}}(\mathrm{t})=\frac{\mathrm{q}_{\mathrm{x}}(\mathrm{t}) \mathrm{MIF}_{\mathrm{x}}(\mathrm{t})}{\mathrm{Q}(\mathrm{t})}=\frac{\mathrm{Q}(\mathrm{t})-\mathrm{Q}(\mathrm{t}) \mid \mathrm{q}_{\mathrm{x}}=0}{\mathrm{Q}(\mathrm{t})}
$$

Burada CIF, kritik önem faktörünü; $Q(t)$, mantık kapısının hata olasılığını; $q_{x}(t)$, $x$ olayının hata olasılığını; $\operatorname{MIF}_{\mathrm{x}}(\mathrm{t})$ marjinal önem faktörünü; $\mathrm{Q}(\mathrm{t}) \mid \mathrm{q}_{\mathrm{x}}=0, \mathrm{q}_{\mathrm{x}}=0$ iken hata olasılı̆̆ını göstermektedir. MIF, bir x olayı meydana geldiğindeki hata olasıllğı ile meydana gelmeme durumundaki hata olasılığı arasındaki farkı ifade etmektedir. Bu çalışma kapsamında bu değerler analiz yapılan yazılım aracılığıyla elde edilmiştir.

Tablo 8'deki değerler önem sıralamasına göre verilmiştir. E3 ile kodlanan zemin ve asansör açıklıklarından düşmeler en büyük kritik önem faktörü değerine sahiptir. Örneğin, diğer ve tanımlamayan düşmeler (E9); deliklere ve çukurlara düşmeler (E5) temel olayları, çatı kaplama malzemelerinin veya çatı pencerelerinin kırılması (H1) minimum kesme kümesine ait korkuluk bulunmaması (I1), uygun olmayan malzeme kullanımı (I2); ağır ekipman düşmeleri (E25) gibi iş kazalarının kritik önem faktörü değerleri diğer kazalara nispeten daha yüksek olduğu görülmektedir. Bununla birlikte iskele üzerinde çalışırken denge kaybı (A1) minimum kesme kümesi yapısı içerisinde yer alan iskelede merdiven olmaması (B1), iskelede korkuluğun olmaması (B3), iş̧̧inin emniyet kemerini kullanmayı ihmal etmesi (C1), işverenin emniyet kemeri temin etmemesi (C2) temel ve gelişmemiş olayları en düşük kritik önem faktörü değerlerine sahiptir.

Buradaki kritik önem faktörlerinin sıralamasını iş kazalarının önlenmesinde veya azaltılmasında önlem alınması gereken sıra şeklinde değerlendirmek mümkün olabilecektir. Çalışmada Türkiye'de meydana gelen iş kazaları ele alındığından, yapılan analiz çalışması ile elde edilen sayısal değerlerin kazalara karşı alınacak önlemlerle ilgili göreceli bir sıralama sunduğu düşünülmektedir.

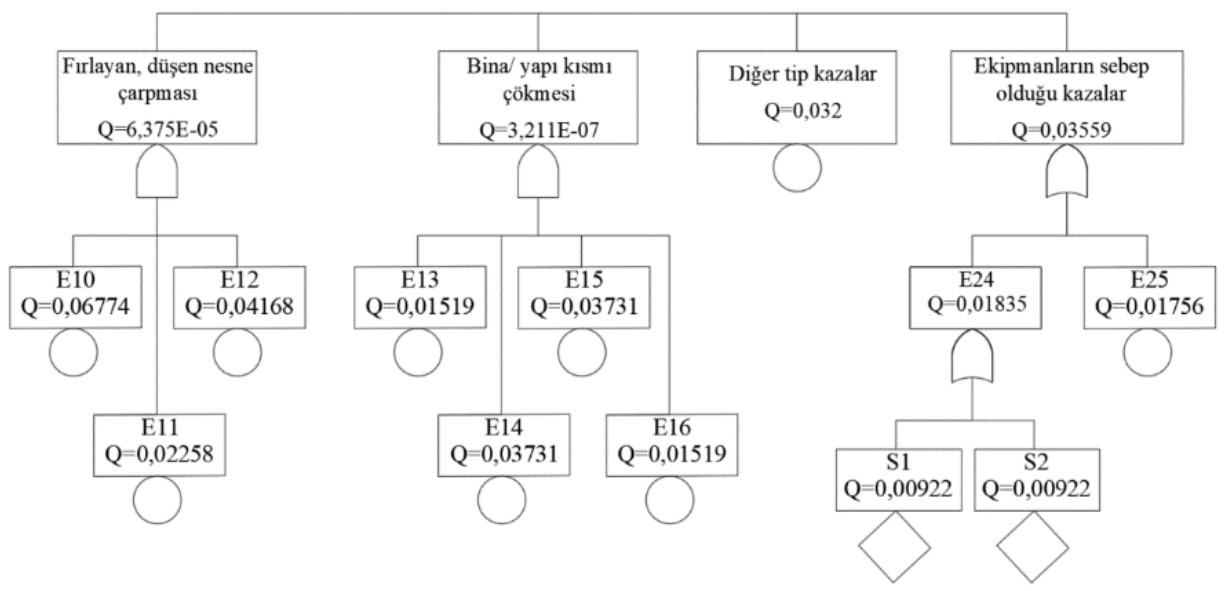

Şekil 8 - Fırlayan düşen nesne çarpması; bina/yapı kısmı çökmesi; diğer tip kazalar; ekipmanların sebep olduğu kazalar; kaza tiplerine ait minimum kesme kümeleri 


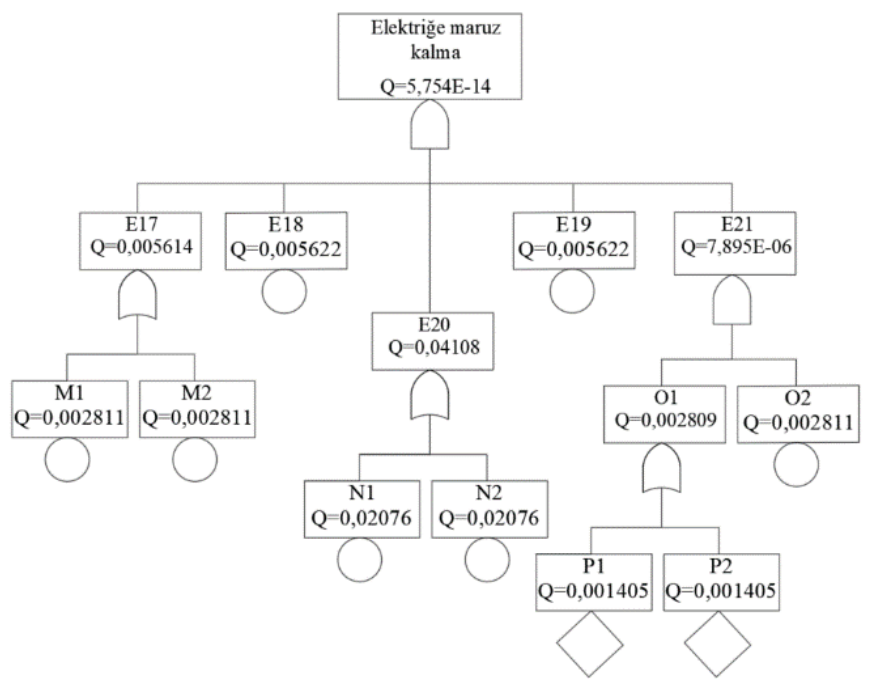

Şekil 9 - Elektriğe maruz kalma kaza tipine ait minimum kesme kümeleri

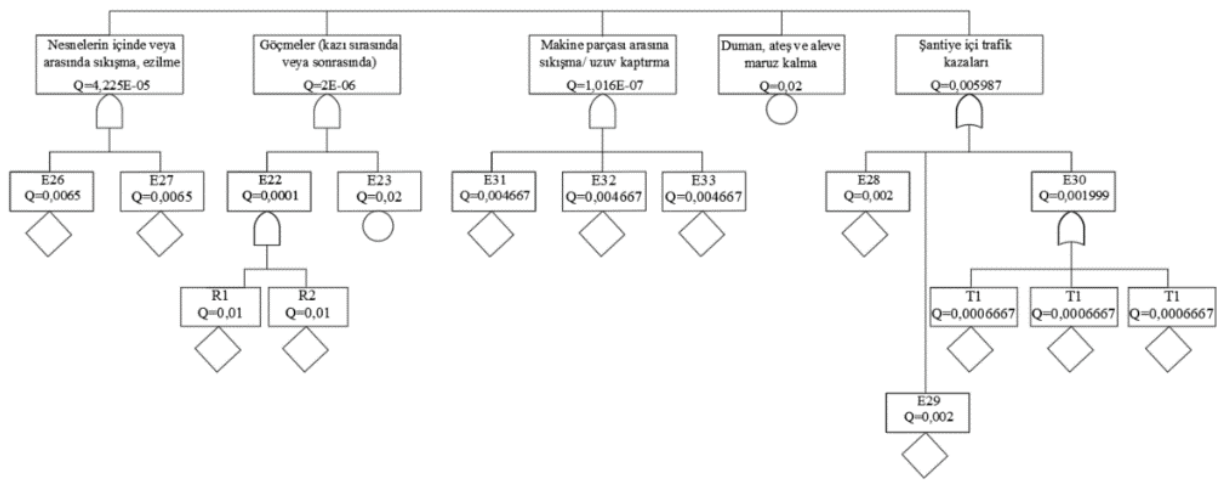

Şekil 10 - Nesnelerin içinde veya arasında sıkışma, ezilme; göçmeler (kazı sırasında veya sonrasında); makine parçası arasına sıkışma/ uzuv kaptırma; duman, ateş ve aleve maruz kalma; şantiye içi trafik kazaları; kaza tiplerine ait minimum kesme kümeleri

\section{SONUÇ}

Bu çalışma kapsamında, Gürcanlı ve Müngen (2013) tarafından incelenmiş olan 1449 adet iş kazasına ait verilerden yararlanılarak bir hata ağacı analizi gerçekleştirilmiştir. Gürcanlı ve Müngen (2013) kapsamında verilen kök nedenler olduğu gibi kullanılmış, kök nedenleri verilmeyen kazalar için de 5 neden analizi yönteminden yararlanılarak hata ağacı yapısı oluşturulmuştur. İş kazası sayılarından yola çıkarak temel ve gelişmemiş olayların olasılık değerleri belirlenmiştir. Hata ağacı analizinde tümdengelimsel bir yaklaşım gerçekleştirildiğinden hata ağacı yapısında aşağıdan yukarıya doğru Boolean matematiği 
aracılığıyla hesaplamalar yapılarak minimum kesme kümelerinin ve en son olarak tepe olayın hata olasılığı değeri belirlenmiştir.

$\mathrm{Bu}$ çalışma ile elde edilen hata ağacı modeli kazaları ve nedenlerinin görsel olarak sunulmasına imkan sağlamaktadır. İnşaatlarda yaşanan iş kazalarıyla ilgili alınacak önlemler sıralamasında dikkate alınabilecek sayısal veriler içermektedir. Minimum kesme kümelerinin hata olasılığı değerleri dikkate alınarak bir önlem sıralaması yapılabilir. Diğer bir önlem alma seçeneği ise çalışma kapsamında sunulan kritik önem faktörleridir. Kritik önem faktörleri önlem almada sıralama ölçeği olarak değerlendirilebilir.

İnşaat sektöründe iş kazaları halen güncelliğini koruyan önemli bir problem olarak karşımıza çıkmaktadır. İş kazalarının çeşitli yöntemlerle analiz edilmesi sektörde önlem alınması gereken kritik noktaları belirlemek açısından önemlidir. Pek çok sektörde kaza ve risk analizi yaparken kullanılan hata ağacı analizi, bu çalışma kapsamında Türkiye'de inşaat sektöründeki iş kazalarının analizi için kullanılmıştır. Hata ağacı analizinin, inşaat sektöründeki iş kazalarının analizinde etkin bir şekilde kullanıldığı görülmektedir. Gelecekteki çalışmalarda farklı iş kazalarının incelenmesiyle güncel veritabanları oluşturulabilir ve bu veriler ile hata ağacı analizi gerçekleştirilebilir.

\section{Kaynaklar}

[1] https://www.ilo.org/, Son Erişim Tarihi: 04.07.2021

[2] 6331 Sayılı İş Sağlığı ve Güvenliği Kanunu, 2012.

[3] Carter G., Smith, S., Safety Hazard Identification on Construction Projects, J. Constr. Eng. Manag., 132(2), 197-205, 2006.

[4] Hinze, J., Thurman, S., Wehle, A., Leading Indicators of Construction Safety Performance, Safety Science, 51(1), 23-28, 2013.

[5] Yang, K., Ahn, C. R., Kim, H., Validating Ambulatory Gait Assessment Technique for Hazard Sensing in Construction Environments, Automation in Construction, 98, 302309, 2019.

[6] Hallowell, M. R., Gambatese, J. A., Construction Safety Risk Mitigation. J. Constr. Eng. Manag., 135(12), 1316-1323, 2009.

[7] Sousa, V., Almeida, N. M., Dias, L. A., Risk-Based Management of Occupational Safety and Health in the Construction Industry - Part 1: Background Knowledge, Safety Science, 66, 75-86, 2014.

[8] Müngen, U., İnşaat Sektörümüzdeki Başlıca İş Kazası Tipleri, Türkiye Mühendislik Haberleri, 469, 32-39, 2011.

[9] Filho, J. M. J., Fonseca, E. D., Lima, F. P. A., Duarte, F. J. C. M., Organizational Factors Related to Occupational Accidents in Construction, Work, 41, 4130-4136, 2012.

[10] Carrillo-Castrillo, J. A., Trillo-Cabello, A. F., Rubio-Romero, J. C., Construction Accidents: Identification of the Main Associations Between Causes, International Journal of Occupational Safety and Ergonomics, 23(2), 240-250, 2017. 
[11] Mohammad M. Z., Hadikusumo, B. H. W., A Model of Integrated Multilevel Safety Intervention Practices in Malaysian Construction Industry, Procedia Engineering, 171, 396-404, 2017.

[12] Hoła, B., Szóstak, M., An Occupational Profile of People Injured in Accidents at Work in the Polish Construction Industry, Procedia Engineering, 208, 43-51, 2017.

[13] Shuang, D., Heng, L., Skitmore, M., Qin, Y., An Experimental Study of Intrusion Behaviors on Construction Sites: The Role of Age and Gender, Safety Science, 115, 425-434, 2019.

[14] Abas, N., H., Noridan, M., R., Rahmat, M. H., Abas, N. A., Ibrahim, N. Q., Causes of Accidents Involving Scaffolding at Construction Sites, Journal of Technology Management and Business, 7(1), 75-86, 2020.

[15] Halim, N. N. A. A., Jaafar, M. H., Kamaruddin, M. A., Kamaruzaman, N. A., Singh, P. S. J., The Causes of Malaysian Construction Fatalities, Journal of Sustainability Science and Management, 15(5), 236-256, 2020.

[16] Etiler N, Çolak B, Biçer U, Barut N., Fatal Occupational Injuries Among Workers in Kocaeli, Turkey, 1990-1999, Int J Occup Environ Health, 10(1), 55-62, 2004.

[17] Çavuş, A., Taçgın, E., Türkiye'de İnşaat Sektöründeki İş Kazalarının Sınıflandırılarak Nedenlerinin İncelenmesi, Academic Platform Journal of Engineering and Science (APJES), 4(21), 13-24, 2016.

[18] Cameron, I., Gillan, G., Duff, A.R., Issues in the Selection of Fall Prevention and Arrest Equipment, Engineering, Construction and Architectural Management, 14(4), 363-374, 2007.

[19] Wu, W., Yang, H., Li, Q., Chew, D., An Integrated Information Management Model for Proactive Prevention of Struck-by-Falling-Object Accidents on Construction Sites, Automation in Construction, 34, 67-74, 2013.

[20] Behm, M., Schneller, A., Application of the Loughborough Construction Accident Causation Model: A Framework for Organizational Learning, Construction Management and Economics, 31(6), 580-595, 2013.

[21] Liao, C. W., Chiang, T. L., Reducing Occupational Injuries Attributed to Inattentional Blindness in the Construction Industry, Safety Science, 89, 129-137, 2016.

[22] Liy, C.H., Ibrahim, S.H., Affandi, R., Rosli, N.A., Nawi, M.N.M., Causes of Fall Hazards in Construction Site Management, International Review of Management and Marketing, 6(8), 257-263, 2016.

[23] Siddula, M., Dai, F., Ye, Y., Fan, J., Classifying Construction Site Photos for Roof Detection: A Machine-Learning Method towards Automated Measurement of Safety Performance on Roof Sites, Construction Innovation, 16(3), 368-389, 2016.

[24] Umer, W., Li, H., Lu, W., Szeto, G. P. Y., Wong, A. Y. Development of a Tool to Monitor Static Balance of Construction Workers for Proactive Fall Safety Management, Automation in Construction, 94, 438-448, 2018. 
[25] Winge, S., Albrechtsen, E., Accident Types and Barrier Failures in the Construction Industry, Safety Science, 105, 158-166, 2018.

[26] Kines, P., Occupational Injury Risk Assessment Using Injury Severity Odds Ratios:Male Falls from Heights in the Danish Construction Industry, Human and Ecological Risk Assessment, 7(7), 1929-1943, 2001.

[27] Hu, K., Rahmandad, H., Smith-Jackson, T., Winchester, W., Factors Influencing the Risk of Falls in The Construction Industry: A Review of the Evidence, Construction Management and Economics, 29(4), 397-416, 2011.

[28] Chi, C. F., Lin, S. Z., Dewi, R. S., Graphical Fault Tree Analysis for Fatal Falls in the Construction Industry, Accident Analysis and Prevention, 72, 359-369, 2014.

[29] Shin, M., Lee, H. S., Park, M., Moon, M., Han, S., A System Dynamics Approach for Modelling Construction Workers' Safety Attitudes and Behaviors, Accident Analysis and Prevention, 68, 95-105, 2014.

[30] Bilir, S., Gürcanl1, G. E., A Method for Determination of Accident Probability in the Construction Industry, Teknik Dergi, 29(4), 8537-8561, 2018.

[31] Baradan, S., Usmen, M. A., Comparative Injury and Fatality Risk Analysis of Building Trades, Journal of Construction Engineering and Management, 132(5), 533-539, 2006.

[32] Guo, B. H., Goh, Y. M., Ontology for Design of Active Fall Protection Systems, Automation in Construction, 82, 138-153, 2017.

[33] Baradan, S., Akboğa, Ö., Çetinkaya, U., Usmen, M. A., Ege Bölgesindeki İnşaat İş Kazalarının Sıklık ve Çapraz Tablolama Analizleri, IMO Teknik Dergi, 27(1), 7345$7370,2016$.

[34] Gürcanlı, G. E., Müngen, U., Analysis of Construction Accidents in Turkey and Responsible Parties, Industrial Health, 51, 581-595, 2013.

[35] Hadipriono, F.C., Expert System for Construction Safety. I: Fault-Tree Models, Journal of Performance of Constructed Facilities, 6(4), 246-260, 1992.

[36] Hadipriono, F.C., Expert System for Construction Safety II: Knowledge Base, Journal of Performance of Constructed Facilities, 6(4), 261-274, 1992.

[37] LeBeau, K. H., Wadia-Fascetti, S. J., 20, Fault Tree Analysis of Schoharie Creek Bridge Collapse, Journal of Performance of Constructed Facilities, 21(4), 320-326, 2007.

[38] Yang, R., Deng, Y., Analysis on Security Risks in Tunnel Construction Based on the Fault Tree Analysis, IOP Conf. Series: Earth and Environmental Science, 2021.

[39] https://ec.europa.eu/eurostat/data/database, Son Erişim Tarihi: 18.10.2021.

[40] http://www.sgk.gov.tr/, Son Erişim Tarihi: 04.07.2021.

[41] Waehrer, G.M., Dong, X.S., Miller, T., Halie, E., Men, Y., Costs of Occupational Injuries in Construction in the United States, Accident Analysis and Prevention, 39(6), 1258-1266, 2007. 
[42] Sacks, R., Rozenfeld, O., Rosenfeld, Y., Spatial and Temporal Exposure to Safetyhazards in Construction, Journal of Construction Engineering and Management, 135(8), 726-736, 2009.

[43] Bertsche, B., Fault Tree Analysis, FTA, Reliability in Automotive and Mechanical Engineering, Springer, Berlin, Heidelberg, 2008.

[44] Ericson, C. A., Fault Tree Analysis- A History, 17th International System Safety Conference, USA, 1999.

[45] Vesely, W., Dugan, J., Fragola, J., Minarick, J., Railsback, J., Fault Tree Handbook with Aerospace Applications, Washington DC. NASA, 2002.

[46] Xing L., Amari S.V., Fault Tree Analysis, Handbook of Performability Engineering, Misra, K. B., Springer, London, 2008.

[47] Lee, W. S., Grosh, D. L., Tillman, F. A., Lie, C. H., Fault Tree Analysis, Methods, and Applications-A Review, IEEE Transactions on Reliability, 34(3), 194-203, 1985.

[48] Whitesitt, J. E., Boolean Algebra and Its Applications, Courier Corporation, Mineola, New York, 2012.

[49] The Institute of Internal Auditors, Practice Advisory 2320-2: Root Cause Analysis, Primary Related Standard, 2320-Analysis and Evaluation, 2011.

[50] Serrat O., The Five Whys Technique, Knowledge Solutions, Springer, Singapore, 2017.

[51] Dizdar, E. N., Fault Tree Analysis For System Reliability, Teknoloji, 6(3-4), 35-40, 2003.

[52] Kum, S., Petrol Tankerlerinde Risk Değerlendirmesi, Yüksek Lisans Tezi, İstanbul Teknik Üniversitesi, 2005. 